\title{
Neurosteroids and GABA-A receptor function
}

\author{
Mingde Wang * \\ Section of Obstetrics and Gynecology, Department of Clinical Science, Umeå Neurosteroid Research Center, Umeå University, Umeå, Sweden
}

\section{Edited by: \\ Hubert Vaudry, University of Rouen, \\ France}

\section{Reviewed by:}

Valerio Magnaghi, Università Degli

Studi di Milano, Italy

Giovanni Biggio, University of Cagliari,

Italy

Remy Schlichter, University

Strasbourg-CNRS, France

\section{*Correspondence:}

Mingde Wang, Section of Obstetrics and Gynecology, Department of Clinical Science, Umeå Neurosteroid Research Center, Umeå University, 90185 Umeå, Sweden.

e-mail:mingde.wang@obgyn.umu.se
Neurosteroids represent a class of endogenous steroids that are synthesized in the brain, the adrenals, and the gonads and have potent and selective effects on the GABAAreceptor. 3 $\alpha$-hydroxy A-ring reduced metabolites of progesterone, deoxycorticosterone, and testosterone are positive modulators of $\mathrm{GABA}_{A}$-receptor in a non-genomic man-

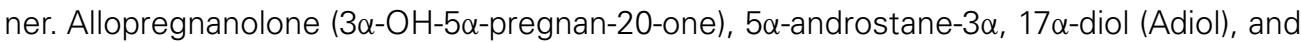
$3 \alpha 5 \alpha$-tetrahydrodeoxycorticosterone $(3 \alpha 5 \alpha-\mathrm{THDOC})$ enhance the GABA-mediated $\mathrm{Cl}^{-}$currents acting on a site (or sites) distinct from the GABA, benzodiazepine, barbiturate, and picrotoxin binding sites. $3 \alpha 5 \alpha-P$ and $3 \alpha 5 \alpha-$ THDOC potentiate synaptic GABA $A_{A}$-receptor function and activate $\delta$-subunit containing extrasynaptic receptors that mediate tonic currents. On the contrary, $3 \beta-\mathrm{OH}$ pregnane steroids and pregnenolone sulfate (PS) are $\mathrm{GABA}_{A}$-receptor antagonists and induce activation-dependent inhibition of the receptor. The activities of neurosteroid are dependent on brain regions and types of neurons. In addition to the slow genomic action of the parent steroids, the non-genomic, and rapid actions of neurosteroids play a significant role in the $\mathrm{GABA}_{A}$-receptor function and shift in mood and memory function. This review describes molecular mechanisms underlying neurosteroid action on the $\mathrm{GABA}_{A}$-receptor, mood changes, and cognitive functions.

Keywords: allopregnanolone, THDOC, pregnenolone sulfate, GABA $A_{A}$-receptor, premenstrual dysphoric disorder, mood, cognition

\section{NEUROSTEROID}

Sex hormones act through genomic mechanisms through the intracellular receptors located in the nucleus or cytoplasm. They act as ligand-activated transcription factors in the regulation of gene expression. However, metabolites of progesterone and several stress hormones act on the membrane bound receptor via a non-genomic mechanism. The receptor binding to DNA and RNA synthesis is thus not required (Frye et al., 1992; Baulieu and Robel, 1995; Rupprecht, 2003). While the genomic action of sex hormones requires a time period from minutes to hours and limited by the rate of protein biosynthesis (McEwen, 1991), the modulation on the membrane receptor is fast occurring event and requires only milliseconds to seconds (McEwen, 1991). Today it is known that metabolites of sex and stress hormones act non-genomically

\footnotetext{
Abbreviations: $3 \beta 5 \beta-\mathrm{P}, 3 \beta-\mathrm{OH}-5 \beta$-pregnan-20-one, epipregnanolone; $3 \beta 5 \alpha-\mathrm{P}$, $3 \beta-\mathrm{OH}-5 \alpha$-pregnan-20-one, isoallopregnanolone; $3 \alpha 5 \alpha-\mathrm{P}, 3 \alpha-\mathrm{OH}-5 \alpha-$ pregnan20 -one, allopregnanolone; $3 \alpha 5 \beta-\mathrm{P}, 3 \alpha-\mathrm{OH}-5 \beta$-pregnan-20-one, pregnanolone; $3 \alpha 5 \alpha$-THDOC, $3 \alpha, 5 \alpha$-tetrahydrodeoxycorticosterone; $3 \alpha 5 \beta$-THDOC, $3 \alpha, 5 \beta-$ tetrahydrodeoxycorticosterone; $3 \beta 5 \beta$-THDOC, $5 \beta$-pregnan-3 $\beta, 21$-diol-20-one; $3 \alpha$-adiol $/ 3 \alpha 5 \alpha$-ADL, $5 \alpha$-androstane- $3 \alpha, 17 \beta$-diol; $3 \beta$-HSD, $3 \beta$-hydroxysteroid dehydrogenase; $3 \alpha-\mathrm{OH}, 3 \alpha$-hydroxy; $3 \beta-\mathrm{OH}, 3 \beta$-hydroxy; CGC, cerebellar granule cells; CNS, central nervous system; DGC, dentate gyrus granule cells; DHEAS, dehydroepiandrosterone sulfate; DOC, deoxycorticosterone; $\mathrm{EC}_{50}$, concentration of drug that produces $50 \%$ of maximum response; GABA, $\gamma$-amino butyric acid; LTP, long-term potentiation; MPA, medroxyprogesterone; MPN, medial preoptic nucleus; nAChRs, nicotinic acetylcholine receptors; NMDA, $N$-methyl-D-aspartate; $\mathrm{P} 450_{21}$, steroid 21 hydroxylase; $\mathrm{P} 450_{\mathrm{c} 17}$, steroid 17 alpha-hydroxylase/17, 20 lyase; PMS/PMDD, premenstrual syndrome/premenstrual dysphoric disorder; PS, pregnenolone sulfate; sIPSC, spontaneous inhibitory postsynaptic current; TBPS, $t$-butyl

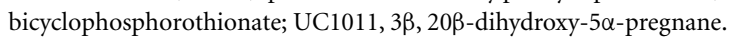

in the CNS and alter neuronal excitability (Majewska et al., 1986; Paul and Purdy, 1992; Lambert et al., 1995).

The term "neurosteroid" was introduced to describe these steroid metabolites that modulate neuronal activity (Paul and Purdy, 1992; Baulieu et al., 2007; Mellon, 2007). The $3 \alpha$-hydroxy A-ring reduced metabolites of progesterone and deoxycorticosterone, allopregnanolone $(3 \alpha 5 \alpha-\mathrm{P})$, and $3 \alpha, 5 \alpha$ tetrahydrodeoxycorticosterone ( $3 \alpha 5 \alpha$-THDOC) were first shown to modulate neuronal excitability by interaction with the $\mathrm{GABA}_{\mathrm{A}}$ receptor (Majewska et al., 1986). Several other neurotransmitters like the NMDA, nicotinic, muscarinic, serotonergic, adrenergic, and sigma 1 receptors are also targets for neurosteroids (Klangkalya and Chan, 1988; Wu et al., 1991; Valera et al., 1992; Compagnone and Mellon, 2000; Mellon et al., 2001; Parry, 2001; Halbreich, 2003; Mellon, 2007). The functional modulation of the $\mathrm{GABA}_{\mathrm{A}}$-receptor by neurosteroids at low concentrations is believed to induce moderate to severe adverse mood changes in up to $20 \%$ of female individuals (Beauchamp et al., 2000; Fish et al., 2001). The clinical complex of premenstrual dystrophic disorders (PMDD; Backstrom et al., 2003; Sundstrom Poromaa et al., 2003), petit mal epilepsy (Grunewald et al., 1992; Banerjee and Snead, 1998), and catamenial epilepsy (Backstrom, 1976) are among the disorders that may involve neurosteroid action. At higher doses, neurosteroids may affect learning (Johansson et al., 2002), act as anxiolytic, anti-aggressive, sedative/anesthetic, and anti-epileptic agents in both animals and humans (Backstrom et al., 1990; Paul and Purdy, 1992; Wang et al., 2001; Bjorn et al., 2002).

As shown in Figure 1, neurosteroids are synthesized in glial cells and neurons of the central and peripheral nervous system 
from cholesterol or steroidal precursors imported from peripheral sources (Schumacher et al., 2000; Baulieu et al., 2007). They include $3 \beta$-hydroxy- $\Delta^{5}$-compounds such as pregnenolone and dehydroepiandrosterone, their sulfate esters and reduced metabolites of steroid and stress hormones such as the tetrahydroderivative of progesterone, $3 \alpha$-hydroxy- $5 \alpha$-pregnan-20-one (allopregnanolone; Baulieu et al., 2007). Progesterone itself is also a neurosteroid, and a progesterone receptor has been detected in peripheral and central glial cells (Schumacher et al., 2000; Baulieu et al., 2007). At different sites in the brain, concentrations of neurosteroids vary according to environmental and behavioral circumstances, such as stress, sex recognition, and aggressiveness. Allopregnanolone can accumulate in the brain after adrenalectomy and gonadectomy (Purdy et al., 1991; Corpechot et al., 1993; Cheney et al., 1995). This indicates that allopregnanolone is synthesized in the brain via A-ring reduction of progesterone (Celotti et al., 1992; Do Rego et al., 2009). Table 1 shows concentrations of major neurosteroids in the plasma and brain.

Pregnenolone sulfate (PS) and dehydroepiandrosterone sulfate (DHEAS) are naturally occurring neurosteroids that inhibit the GABA $_{A}$-receptor (Paul and Purdy, 1992). PS is synthesized from pregnenolone by the enzyme sulfotransferase (Figure 1). Conversion from DHEA to DHEAS is also mediated by sulfotransferase. DHEA is metabolized from pregnenolone by cytochrome $\mathrm{P} 450_{\mathrm{C} 17}$ (Mensah-Nyagan et al., 1999). On the other hand, 3 $\beta$ HSD is essential for the synthesis of $3 \beta-\mathrm{OH}$ steroids, i.e., $3 \beta-\mathrm{OH}-$ $5 \alpha$-pregnan-20-one (isoallopregnanolone; $3 \beta 5 \alpha-\mathrm{P}$ ) and $3 \beta-\mathrm{OH}$ $5 \beta$-pregnan-20-one (epipregnanolone; $3 \beta 5 \beta$-P; Stromstedt et al., 1993). PS, DHEAS, and $3 \beta-\mathrm{OH}$ steroids act as antagonists on the GABA $_{A}$-receptor (Wang et al., 2002; Eisenman et al., 2003) and can be measured from human blood samples (Hill et al., 2001).

As metabolites of stress hormone deoxycorticosterone (DOC), $3 \alpha 5 \alpha$-THDOC and $3 \alpha 5 \beta$-THDOC are also potent modulators of the $\mathrm{GABA}_{\mathrm{A}}$-receptor (Crawley et al., 1986; Majewska et al., 1986; Gasior et al., 1999; Lambert et al., 2001a). Both steroids have significant sedative effects in vivo. $3 \alpha 5 \alpha$-THDOC is responsible for the sedative and anti-seizure activity of DOC in animal models (Reddy and Rogawski, 2002). DOC can be metabolized from progesterone and this conversion is mediated by $\mathrm{P}^{4} 50_{21}$ (Edwards et al., 2005). The conversion of DOC to $3 \alpha 5 \alpha$-THDOC occurs both in peripheral tissues and in the brain (Reddy, 2003). The A-ring reduced metabolite of testosterone, $5 \alpha$-androstane- $3 \alpha, 17 \beta$ diol $\left(3 \alpha 5 \alpha\right.$-adiol), acts also as a $\mathrm{GABA}_{\mathrm{A}}$-receptor agonist (Frye et al., 1996).

\section{$\mathrm{GABA}_{\mathrm{A}}-\mathrm{RECEPTOR}$}

GABA mediates most of the inhibitory neurotransmission in the mammalian brain. GABA-mediated inhibition is crucially in both short-term and long-term regulation of neuronal excitability. It has been estimated that approximately $33 \%$ of the synapses in the mammalian cerebral cortex are GABAergic (Purvez et al., 2004). Two major types of receptors, $\mathrm{GABA}_{\mathrm{A}}$ - and $\mathrm{GABA}_{\mathrm{B}}$-receptors can be identified in the CNS (Sivilotti and Nistri, 1991; Bormann, 2000). It appears that neurosteroids more or less exclusively target the $\mathrm{GABA}_{\mathrm{A}}$-receptor which is a ligand gated anion-selective channel (Schofield et al., 1987).

Various isoforms of the $\mathrm{GABA}_{\mathrm{A}}$-receptor have been identified that comprise $\alpha_{1-6}, \beta_{1-3}, \gamma_{1-3}, \delta, \varepsilon, \pi, \theta$, and $\rho_{1-3}$ subunits (Amin and Weiss, 1994; Mehta and Ticku, 1999; Rudolph et al., 2001). In general, $\mathrm{GABA}_{\mathrm{A}}$-receptors are pentameric proteins (Nayeem et al., 1994) that are built of five subunits which includes two $\alpha$-subunits, two $\beta$-subunits and one subunit of either the $\gamma-, \delta-, \varepsilon-, \pi-$, or $\theta$-type (Farrar et al., 1999; Knight et al., 2000; Klausberger et al., 2001). A subgroup of $\mathrm{GABA}_{\mathrm{A}}$-receptor channels was named as $\mathrm{GABA}_{\mathrm{C}^{-}}$ receptor earlier and composed of homo-oligomeric $\rho_{1-3}$ subunits. They are pharmacologically distinct from other $\mathrm{GABA}_{\mathrm{A}}$-receptor channels and this difference is illustrated by the insensitivity of $\rho$ receptor channels to many known modulators such as barbiturates and benzodiazepine (Amin and Weiss, 1994, 1996).

Immunological, pharmacological, and functional analysis give the evidence that the $\alpha_{1} \beta_{2} \gamma_{2}$ combination is the most common $\mathrm{GABA}_{\mathrm{A}}$-receptor within the CNS $(\sim 60 \%)$, followed by $\alpha_{2} \beta_{3} \gamma_{2}$ ( $\sim 15-20 \%)$ and $\alpha_{3} \beta_{n} \gamma_{2}(\sim 10-15 \%, n=1,2$, or 3; Mohler et al., 2002, 2004; Fritschy and Brunig, 2003; Wallner et al., 2003). Receptors containing the $\alpha_{4^{-}}, \alpha_{5^{-}}$, and $\alpha_{6}$-subnit, as well as the $\beta_{1^{-}}, \gamma_{1-3}$, $\delta-, \pi-$, and $\theta$-subunit, form a minor receptor population. Each of

Table 1 | Neurosteroid concentrations in human plasma and brain (mean \pm SEM).

\begin{tabular}{|c|c|c|c|c|}
\hline \multirow[t]{2}{*}{ Steroids } & \multicolumn{2}{|c|}{ Plasma (nM) } & \multicolumn{2}{|c|}{ Brain (nM) } \\
\hline & Follicular & Luteal & Postmenopausal & Luteal \\
\hline Progesterone & $5.0 \pm 0.50$ (Wang et al., 1996) & $34.7 \pm 2.40$ & 65 (Bixo et al., 1997) & 137 (Bixo et al., 1997) \\
\hline $3 \alpha-\mathrm{OH}-5 \beta$-pregnan-20-one & $0.6 \pm 0.00$ (Sundstrom et al., 1998) & $1.1 \pm 0.50$ & - & 114 (Bixo et al., 1997) \\
\hline $3 \alpha-\mathrm{OH}-5 \alpha$-pregnan-20-one & $\begin{array}{l}\text { 0.2-0.6 Wang et al., 1996; } \\
\text { Genazzani et al., 1998) }\end{array}$ & $\begin{array}{l}\text { 2-4 Wang et al., 1996; } \\
\text { Genazzani et al., 1998) }\end{array}$ & 47 (Bixo et al., 1997) & 66 (Bixo et al., 1997) \\
\hline $3 \beta-\mathrm{OH}-5 \alpha$-pregnan-20-one & $\begin{array}{l}\text { 0.3-0.5 Wang et al., 1996; } \\
\text { Sundstrom et al., 1998)) }\end{array}$ & $\begin{array}{l}\text { 1.5-3.5 Wang et al., 1996; } \\
\text { Sundstrom et al., 1998) }\end{array}$ & - & - \\
\hline $3 \beta-\mathrm{OH}-5 \beta$-pregnan-20-one & $0.09 \pm 0.08$ (Havlikova et al., 2006) & $0.26 \pm 0.13$ & - & - \\
\hline Pregnenolone sulfate & $11.2 \pm 0.6$ (Wang et al., 1996) & $15.2 \pm 0.8$ (Bixo et al., 1997) & - & $\begin{array}{l}100 \text { (Lanthier and Pat- } \\
\text { wardhan, 1986) }\end{array}$ \\
\hline Pregnenolone & ${ }^{*} 2.19$ (Kancheva et al., 2007) & - & - & - \\
\hline $3 \alpha 5 \alpha$-androstane- $3 \alpha, 17 \beta$-diol & *0.475 (Kancheva et al., 2007) & - & - & - \\
\hline
\end{tabular}

Data cited from references are inserted as indicated. ${ }^{*}$ Concentration in adult men. 


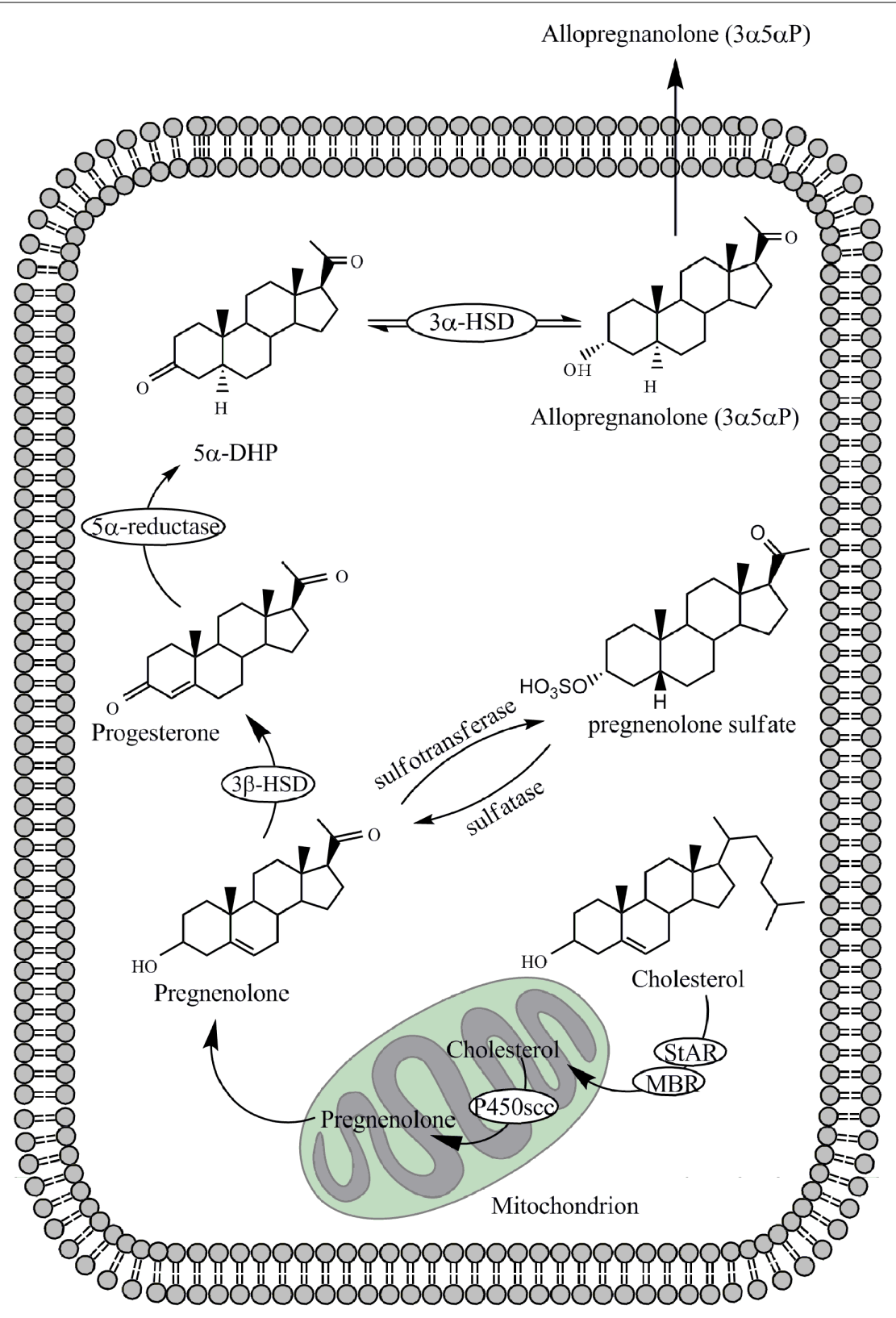

FIGURE 1 | Biosynthesis of allopregnanolone and pregnenolone sulfate (PS) from cholesterol within the neuron or glial cell. Enzymes involved are P450 side-chain cleavage (P450scc), 3 $\alpha$-hydroxysteroid

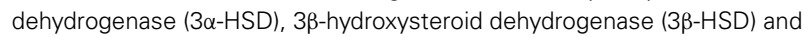

$5 \alpha$-reductase. Transport of cholesterol across the mitochondrial membrane is enhanced by the steroidogenic acute-regulatory (StAR) protein and the mitochondrial benzodiazepine receptor (MBR). $5 \alpha$-DHP represents $5 \alpha$-dihydroprogesterone. the $\alpha_{4} \beta_{n} \delta, \alpha_{4} \beta_{n} \gamma$, and the $\alpha_{6} \beta_{2 / 3} \gamma_{2}$ receptor accounts less than $5 \%$ of all the $\mathrm{GABA}_{\mathrm{A}}$-receptor quantity (McKernan and Whiting, 1996; Whiting, 2003a,b). The $\alpha_{6} \beta_{n} \delta$ receptor has a small population in the cerebellum and the $\alpha_{6} \beta_{2 / 3} \gamma_{2}$ receptor located exclusively in the cerebellum (McKernan and Whiting, 1996; Whiting, 2003a,b).

The expression of $\mathrm{GABA}_{\mathrm{A}}$-receptor subtypes in the adult brain exhibits a remarkable regional and neuronal specificity which suggests that individual subtypes are present in distinct neuronal circuits. The $\alpha_{1} \beta_{2} \gamma_{2}$ receptor is present in most brain areas and it is localized to interneurons in the hippocampus and cortex (layer I-IV), and cerebral Purkinje cells (McKernan and Whiting, 1996). The $\alpha_{2} \beta_{3} \gamma_{2}$ receptor is present in cerebral cortex (layer IIV), hippocampal formation, amygdale, striatum, olfactory bulb, hypothalamus, superior colliculi, and motor nuclei (Fritschy and Brunig, 2003). The $\alpha_{3} \beta_{n} \gamma_{2}, \alpha_{3} \gamma_{2}$, and $\alpha_{3} \theta$ receptors are abundant in the cerebral cortex (layers V-VI), amygdala, olfactory bulb, thalamic reticular and intralaminar nuclei, superior colliculus, brainstem, spinal cord, and locus coeruleus. The $\alpha_{4} \beta_{n} \delta(n=1,2$, 
or 3 ) receptor is presented in the dentate gyrus and thalamus. The $\alpha_{5} \beta_{3} \gamma_{2}$ receptor is widespread in the hippocampus and dentate gyrus (Glykys et al., 2008), deep cortical layers, amygdala, olfactory bulb, hypothalamus, superior colliculus, superior olivary nucleus, spinal trigeminal nucleus, and spinal cord. The $\alpha_{6} \beta_{2 / 3} \gamma_{2}, \alpha_{6} \beta_{2 / 3} \delta$, and $\alpha_{6} \beta_{2 / 3} \gamma_{2}$ receptors are found mainly in the cerebellum and dorsal cochlear nucleus (Fritschy and Brunig, 2003).

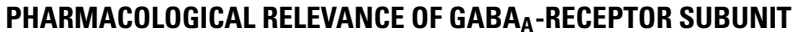 COMPOSITIONS}

Especially the different $\alpha$-subunits have been attributed to specific behavioral effects as shown in Table 2. For example, an enhancement at the $\alpha_{1}$ subunit has been associated with sedation (Rudolph et al., 1999) and the $\alpha_{2}$ with anxiolytic action. Recently, it has been shown that the $\alpha_{5}$ subunit is important for sedative tolerance development to benzodiazepines and for acquisition and expression of associative memory and spatial learning (Collinson et al., 2002; Crestani et al., 2002; van Rijnsoever et al., 2004; Yee et al., 2004). In addition, the $\alpha_{4}$ subunit is also implicated in the regulation of anxiety (Gulinello et al., 2001). A concentration-dependent decrease of the $\alpha_{4}$ subunit is seen after 4-day application of allopregnanolone to developing neuronal cells (Grobin and Morrow, 2000). In the hippocampus and cerebellum, an increase of the $\alpha_{4}$ subunit can be detected after withdrawal from chronic exposure and after short-term treatment of progesterone and allopregnanolone (Smith et al., 1998; Concas et al., 1999; Follesa et al., 2001; Gulinello et al., 2001). The $\alpha_{6}$ subunit is highly sensitive to pentobarbital (Thompson et al., 1996) and neurosteroids (Belelli et al., 2002).

The $\gamma_{2}$ subunit is also involved in anxiety regulation, and it is changed during hormone treatment and pregnancy (Essrich et al., 1998; Follesa et al., 1998; Concas et al., 1999; Crestani et al., 1999; Kittler et al., 2000). The $\delta$-subunit is responsible for tonic conductance and important for neurosteroid modulation on $\mathrm{GABA}_{\mathrm{A}}$-receptor (Stell et al., 2003). Interestingly, receptor knockout studies have revealed that the absence of the $\delta$-subunit decreases the sensitivity to neurosteroids such as pregnanolone and alphaxalone, thereby influencing the duration of anesthesia and the anxiolytic effect of those steroids (Mihalek et al., 1999). Finally, the $\varepsilon$-subunit reduces neurosteroid and anesthetic modulation (Davies et al., 1997; Belelli et al., 2002; Thompson et al., 2002).

Functionally, distinct subunit-specific properties have been identified in both recombinant and native receptors, supporting the concept that $\mathrm{GABA}_{\mathrm{A}}$-receptor heterogeneity is a major facet determining the functional properties of GABAergic inhibitory circuits (Sieghart, 2000; Mohler et al., 2001). In particular, the type of $\alpha$-subunit determines the kinetics of receptor deactivation (Verdoorn et al., 1990; Hutcheon et al., 2000; Devor et al., 2001), and the presence of the $\delta$-subunit results in markedly increased agonist affinity and apparent lack of desensitization (Burgard et al., 1996; Fisher and Macdonald, 1997; Adkins et al., 2001).

The $\mathrm{GABA}_{\mathrm{A}}$-receptor expresses different subunit compositions in different parts of the brain (Sieghart and Sperk, 2002). The subunit composition is related to different function of the specific part of the brain (Korpi et al., 2007; Table 2). This anatomical diversity constitutes the very basis for the pathogenesis of different conditions. Steroids interact differently with the $\mathrm{GABA}_{\mathrm{A}}$-receptor depending on the subunit composition (Belelli et al., 2002). The $\alpha_{5}$ subunit is localized in high degree in the hippocampus, a key area for memory and learning, $\alpha_{5}$ is shown to be important for learning and memory function (Table 2) since $\alpha_{5}$-subunit knockout mice in comparison with wild-type mice show significantly better performance in a water maze model of spatial learning (Collinson et al., 2002). In addition, blockade of the $\mathrm{GABA}_{\mathrm{A}}$ receptor subunit $\alpha_{5}$ increased learning and memory (Casula et al., 2001; Maubach, 2003). GABA -receptor activation can inhibit LTP induction and NMDA receptors, which are involved in the regulation of hippocampal-dependent spatial memory (Riedel et al., 2003).

Several papers report changes in the $\mathrm{GABA}_{\mathrm{A}}$-receptor subunit composition and decreased GABA function after long-term exposure to $\mathrm{GABA}_{\mathrm{A}}$-receptor agonists (Miller et al., 1988; Belelli et al., 2002). It is well-known that tolerance develops during longterm $\mathrm{GABA}_{\mathrm{A}}$-receptor exposure. Tolerance development is noted already after $90 \mathrm{~min}$ exposure to anesthetic dosages of allopregnanolone. Changes in the $\alpha_{4}$ subunit of the $\mathrm{GABA}_{\mathrm{A}}$-receptor in thalamus were related to the tolerance development (Birzniece et al., 2006a). GABA-steroids are positive neurosteroid modulators on the $\mathrm{GABA}_{\mathrm{A}}$-receptor (Majewska et al., 1986). Long-term treatment with GABA-steroids may induce down-regulation of the $\mathrm{GABA}_{\mathrm{A}}$-receptor function in mammalian cultured neurons both for neuroactive steroids and other $\mathrm{GABA}_{\mathrm{A}}$-receptor active drugs (Yu and Ticku, 1995a; Yu et al., 1996). During pregnancy when allopregnanolone is high there is a decrease in $\mathrm{GABA}_{\mathrm{A}}$-receptor function and changes in subunit composition of the $\mathrm{GABA}_{\mathrm{A}}$ receptor. Inhibiting the synthesis of allopregnanolone blocked these changes (Concas et al., 1998). Chronically high cortisol levels

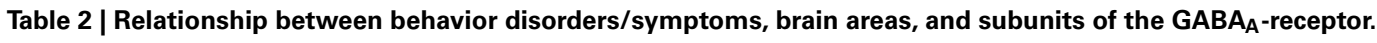

\begin{tabular}{|c|c|c|c|c|}
\hline \multirow{2}{*}{$\begin{array}{l}\text { Behavior disorders/symptoms } \\
\text { Memory and learning disruption }\end{array}$} & \multirow{2}{*}{$\begin{array}{l}\text { Brain region } \\
\text { Hippocampus }\end{array}$} & \multicolumn{3}{|c|}{ GABA $_{A}$-receptor subunit } \\
\hline & & $\alpha_{5}$ & & $\delta$ \\
\hline Anxiety and mood disturbance & Hippocampus; amygdale & $\alpha_{2} \alpha_{4}$ & $\beta_{3}$ & $\delta$ \\
\hline Fatigue, sedation, and exhaustion & Wide spread & $\alpha_{1}$ & & \\
\hline Depression induced by stress & & $\alpha_{1} \alpha_{3}$ & $\beta_{1} \beta_{2}$ & $\delta \gamma_{2}$ \\
\hline Eating disorders & Hypothalamus & & $\alpha_{3}$ & \\
\hline Relapse in alcohol abuse & & $\beta_{6}$ & & \\
\hline Balance and mobility disorders & Cerebellum & $\alpha_{6}$ & $\beta_{2}$ & $\delta$ \\
\hline Epilepsy and excitability disorders & & $\alpha_{1}$ & $\beta_{3}$ & \\
\hline
\end{tabular}


and GABA-steroids give irreversible cognitive damages. A reduced sensitivity to benzodiazepines, alcohol, and GABA-steroid is also seen in women with PMDD during the luteal phase. Such a change in $\mathrm{GABA}_{\mathrm{A}}$-receptor sensitivity, as measured by reduced sedation and saccadic eye velocity response to GABA active compounds, contributes to symptom severity of PMDD patients (Backstrom et al., 2003). In a rat model of PMDD, allopregnanolone upregulates the $\alpha_{4}$ subunit of the $\mathrm{GABA}_{\mathrm{A}}$-receptor in hippocampus parallel to the induction of anxiety (Smith et al., 1998; Gulinello et al., 2001). In addition, the anxiety induction was blocked if the animals were treated with $\alpha_{4}$-antisense (Smith et al., 1998; Gulinello et al., 2001). With a further developed rat model of PMDD, the authors addressed that the high risk-taking rats are those react with anxiety in the PMDD model (Lofgren et al., 2006).

\section{SYNAPTIC AND EXTRASYNAPTIC GABA $A_{A}$-RECEPTORS}

The $G_{A B A}$-receptors can either be synaptic (located within the synaptic cleft) or extrasynaptic (located outside the synaptic cleft; Fortin et al., 2004). The synaptic receptors usually contain $\gamma$-subunits and can be rapidly expressed at the neuronal membrane and are sensitive to both benzodiazepines and neurosteroids. Extrasynaptic $\mathrm{GABA}_{\mathrm{A}}$-receptors are in a preferred position to be activated by the low levels of ambient GABA, due to their high GABA affinity in contrast to the lower affinity of synaptic GABA receptors (Saxena and Macdonald, 1994; Mody, 2001; Brown et al., 2002; Farrant and Nusser, 2005). The high-affinity extrasynaptic $\mathrm{GABA}_{\mathrm{A}}$-receptors consist of specific subunit combinations differentially expressed in various brain regions. These include the $\delta$-subunit containing $\mathrm{GABA}_{\mathrm{A}}$-receptors of dentate gyrus and cerebellar granule cells, cortical and thala mic neurons (Nusser et al., 1998; Sur et al., 1999; Pirker et al., 2000; Nusser and Mody, 2002; Stell et al., 2003; Sun et al., 2004; Cope et al., 2005; Jia et al., 2005; Drasbek and Jensen, 2006), and the $\alpha_{5}$-subunit containing $\mathrm{GABA}_{\mathrm{A}}$-receptors in CA1 and CA3 pyramidal cells (Sperk et al., 1997; Caraiscos et al., 2004; Glykys and Mody, 2006). The current mediated by these extrasynaptic receptors has been termed tonic inhibition (Brickley et al., 1996; Farrant and Nusser, 2005), which is highly sensitive to the extracellular GABA concentration (GABA). It is enhanced when ambient (GABA) is increased by blocking GABA transporters, by adding GABA to the aCSF to mimic that normally present in the extracellular space, or by preventing GABA degradation (Nusser and Mody, 2002; Stell and Mody, 2002; Wu et al., 2003; Glykys and Mody, 2006).

The $\delta$-subunit is highly sensitive to GABA and neurosteroids but not to benzodiazepines (Brown et al., 2002; Smith et al., 2007). It also appears that specific types of receptor subunit combinations are expressed in the synaptic cleft and extra synaptically. For example, the $\alpha_{1} \beta_{2 / 3} \gamma_{2}, \alpha_{2} \beta_{2 / 3} \gamma_{2}$, and $\alpha_{3} \beta_{2 / 3} \gamma_{2}$ receptors are the predominant synaptic receptors (Farrant and Nusser, 2005) and the combinations of $\alpha_{6} \beta_{n} \delta, \alpha_{4} \beta_{n} \delta, \alpha_{1} \beta_{n} \delta$, and $\alpha_{5} \beta_{n} \gamma_{2}$ receptors, are predominantly or exclusively extrasynaptic (Nusser et al., 1998; Fritschy and Brunig, 2003; Glykys and Mody, 2007). In the synapse, each vesicle is thought to release several thousands of GABA molecules into the synaptic cleft which leads to a high concentration of GABA $(0.3-1.0 \mathrm{mM})$ in a time span of 10-100 ms (Mozrzymas et al., 2003; Semyanov et al., 2004). Furthermore, it is suggested that there are rather few receptors, from 10 to a few hundreds, located opposite to the release site (Mody et al., 1994; Nusser et al., 1997; Brickley et al., 1999).

Synaptically released GABA which act on postsynaptic $\mathrm{GABA}_{\mathrm{A}}$ receptors is termed "phasic" inhibition, whereas the term "tonic" inhibition refers to a continuous activation of extrasynaptic receptors by ambient GABA (Farrant and Nusser, 2005). The main feature of phasic inhibition is the rapid synchronous opening of a relatively small number of channels that are clustered within the synaptic cleft. This enables a resolution both in time (the release is triggered by an incoming action potential) as well as in space (the release is limited and thereby the postsynaptic action, to a specific synapse. In contrast, tonic inhibition results from ambient GABA and therefore is relatively constant in both time and space. Although both modes of action clearly impact upon neuronal information processing at the cellular and network level, the extent to which each type of inhibition influences brain excitability in normal and diseased states is not known. GABA-mediated tonic conductance is found in granule cells of the dentate gyrus (Nusser and Mody, 2002; Farrant and Nusser, 2005), thalamocortical relay neurons of the ventral basal complex (Porcello et al., 2003), layer V pyramidal neurons in the somatosensory cortex (Yamada et al., 2004), CA1 pyramidal cells (Bai et al., 2001), and certain inhibitory interneurons in the CA1 region of the hippocampus (Semyanov et al., 2003). Unlike receptors mediating phasic current, tonically active $\mathrm{GABA}_{\mathrm{A}}$-receptors show unusual high GABA affinity (Saxena and Macdonald, 1996) and be activated by the low ambient GABA concentrations (nanomolar to few micromolar; Lerma et al., 1986; Tossman et al., 1986). At sub-micromolar concentrations, several competitive, and noncompetitive $\mathrm{GABA}_{\mathrm{A}}$-receptor antagonists (gabazine, picrotoxin, and bicuculline) reduced phasic currents, but had no effect on tonic currents. However, the antagonists blocked both phasic and tonic currents at high concentrations (Bai et al., 2001; Stell and Mody, 2002; Semyanov et al., 2003; Yeung et al., 2003; Farrant and Nusser, 2005).

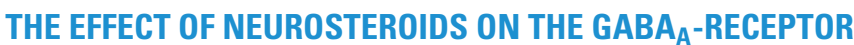

The $\mathrm{GABA}_{\mathrm{A}}$-receptor can be modulated by a number of therapeutic agents, including benzodiazepines (Sieghart, 1992; Macdonald and Olsen, 1994), barbiturates (Smith and Riskin, 1991), anesthetics, ethanol (Harris et al., 1995), zinc (Smart, 1992), and neurosteroids (Puia et al., 1990; Hawkinson et al., 1994a; Lambert et al., 2001b). The effect of neurosteroids on the $\mathrm{GABA}_{\mathrm{A}}$ receptor depends on the type of steroids (agonist or antagonist), the type of receptors (synaptic of extrasynaptic), the subunit compositions, and the intrinsic structure of the steroid. Recent studies indicate that the existence of at least two neurosteroid actions on the $\mathrm{GABA}_{\mathrm{A}}$-receptor, namely an agonistic action and an antagonistic action by the sulfated and $3 \beta-\mathrm{OH}$ steroids. The agonistic action can further be divided into an allosteric enhancement of GABA-evoked $\mathrm{Cl}^{-}$current and a direct activation of the $\mathrm{GABA}_{\mathrm{A}}$-receptor.

The synaptic currents originates from a short exposure of high concentrations of GABA that induces receptor desensitization (Jones and Westbrook, 1995). As a consequence of this, the mechanism of neurosteroid modulation at the $\mathrm{GABA}_{\mathrm{A}}$-receptor cannot easily be predicted by studies of currents evoked by low 
concentrations of GABA. It has been shown that allopregnanolone remarkably increases the decay time of sIPSC (Haage and Johansson, 1999; Belelli and Lambert, 2005), which likely depends on a reduced GABA unbinding rate from the receptor. However, a different mechanism was suggested for the $3 \alpha 5 \alpha$-THDOC induced decay time prolongation. Here it was instead suggested that the underlying mechanism was altered kinetics of desensitized states (Zhu and Vicini, 1997). The above explanations for the mechanisms underlying the effects of neurosteroids is based on the idea that once GABA is bound to the receptor it can enter different states of which some are open and some are closed (desensitized) which will determine the shape of the evoked current (Jones and Westbrook, 1995).

At low-micromolar concentrations of GABA, allopregnanolone instead increases the activation rate and induces a more prominent desensitization of GABA-evoked currents (Haage and Johansson, 1999). Interestingly, there is also evidence that the effect of $3 \alpha 5 \alpha$-THDOC to prolong the deactivation time (which is the same as the decay time but is used for externally applied GABA) depends on the age. The effect on the deactivation of GABA response in cerebellar neurons is greater in younger rats than adult rats (Zhu and Vicini, 1997). In summary, we believe that the prolongation of deactivation and altered receptor kinetics in terms of entry and exit from desensitized states, are essential to the allosteric modulation of the $\mathrm{GABA}_{\mathrm{A}}$-receptor by neurosteroids. Agonistic neurosteroids affect not only the time course of sIPSC but also the frequency of the sIPSCs. Such an increase in frequency is due to the presynaptic effect of neurosteroids (Poisbeau et al., 1997; Haage et al., 2002) by a mechanism that involves altered presynaptic $\mathrm{Ca}^{2+}$ permeability and activation of presynaptic $\mathrm{GABA}_{\mathrm{A}}$-receptors.

The effect of neurosteroids on the $\mathrm{GABA}_{\mathrm{A}}$-receptor can be attributable to variations in the receptor subunit composition. The action of allopregnanolone was not influenced by the $\alpha$ subunit, when co-expressed with $\beta_{1}$ - and $\gamma_{2}$-subunit in Xenopus oocytes (Belelli et al., 2006). The GABA responses at $\alpha_{1} \beta_{1} \gamma_{2}$ and $\alpha_{3} \beta_{1} \gamma_{2}$ receptor are enhanced by low concentration of allopregnanolone $(\geq 3 \mathrm{nM})$, whereas several folds higher concentrations

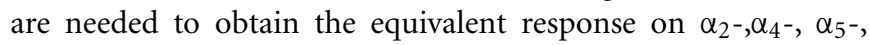
or $\alpha_{6}$-subunit containing receptors. Likewise, the subtypes of the $\beta$-subunit $\left(\beta_{1-3}\right)$ have little action on the effects of neurosteroids (Hadingham et al., 1993; Sanna et al., 1997; Belelli et al., 2002). The presence of a $\gamma$-subunit is not a prerequisite for the neurosteroid activity. In fact, the efficacy of allopregnanolone action at the binary $\alpha_{1} \beta_{1}$ receptor is higher than that at the ternary $\alpha_{1} \beta_{1} \gamma_{2}$ receptors (Maitra and Reynolds, 1999; Belelli et al., 2002). Given the $\gamma$-subunit have little or no effect on the maximal GABA-modulation effect of allopregnanolone, it significantly influences the potency of the steroid with "physiological concentrations" (3-30 nM; Belelli et al., 2002). However, the inhibition of $\mathrm{GABA}_{\mathrm{A}}$-receptor by PS did not vary between binary and ternary receptor (Wang et al., 2006). The potencies and efficacies of PS to inhibit GABA saturating concentration at the $\alpha_{1} \beta_{2} \gamma_{2}$ and $\alpha_{1} \beta_{2}$ receptor were identical (Wang et al., 2006). On the other hand, $\delta$-subunit when co-expressed with $\alpha_{4}$ - and $\beta_{3}$-subunits, a receptor thought to be naturally present in the thalamus (Sur et al., 1999) shows high steroid sensitivity compare to $\gamma$-subunit containing receptor (Davies et al., 1997; Belelli et al., 2002). Receptors incorporating the $\varepsilon$-subunit are reported to be insensitive to the modulation by pregnane steroids, not the direct GABA-mimetic effect (Lambert et al., 2001b).

\section{SYNAPTIC EFFECT OF NEUROSTEROIDS}

The brief inhibitory response of neurosteroids by activating the postsynaptic $\mathrm{GABA}_{\mathrm{A}}$-receptor is a phasic response. Synaptic $\mathrm{GABA}_{\mathrm{A}}$-receptors are ternary complexes that commonly incorporate the $\gamma_{2}$ subunit in combination with one $\alpha$ (mainly $\alpha_{1 / 2 / 3}$ ) and one $\beta_{2 / 3}$ subunit. However, these receptor isoforms can also be located extrasynaptically (Farrant and Nusser, 2005). The kinetic of agonist steroids at synaptic $\mathrm{GABA}_{\mathrm{A}}$-receptor has been studied thoroughly by measuring the sIPSC from neurons in brain slice. Neurosteroids have little effect on the onset time and peak amplitude of the sIPSC. Agonist neurosteroids prolong the decay time constant of IPSC (Majewska et al., 1986; Zhu and Vicini, 1997; Haage et al., 2005). However, this effect is neuron specific. In hippocampal CA1 neurons, cerebellar granule cells and Purkinje neurons, neurosteroids prolong the sIPSC at relatively low concentration (in the nanomolar range; Cooper et al., 1999; Vicini et al., 2002; Harney et al., 2003). On the other hand, micromolar concentrations are required to produce equivalent responses in oxytocin neurons of hypothalamus (Brussaard et al., 1997; Koksma et al., 2003). Moreover, in the preoptic cells in the hypothalamus, $100 \mathrm{nM}$ allopregnanolone prolong the spontaneous current (Haage et al., 2005; Stromberg et al., 2006). This indicates that the neurons in the same brain region can show heterogeneity. In addition, the effect of $3 \alpha 5 \alpha$-THDOC on GABA-binding kinetic is more profound in the hippocampal CA3 and subiculum than that in CA1 and entorhinal cortex (Nguyen et al., 1995). At higher concentrations $(>10 \mu \mathrm{M})$ which can occur in the brain during parturition (Stoffel-Wagner, 2003), neurosteroids activate the $\mathrm{GABA}_{\mathrm{A}}$ receptor directly (Majewska et al., 1986) in a similar pattern as barbiturates by interacting with different sites on $\mathrm{GABA}_{\mathrm{A}}$-receptor (Kerr and Ong, 1992). This "GABA-mimetic" effect of neurosteroid is sufficient to suppress the excitatory neurotransmission (Shu et al., 2004).

\section{EXTRASYNAPTIC EFFECT OF NEUROSTEROIDS}

The response of neurosteroids at relatively low concentrations is mediated by the activation of extrasynaptic $\mathrm{GABA}_{\mathrm{A}}$-receptors containing $\alpha_{4}, \alpha_{6}$, and $\delta$-subunits. Extrasynaptic receptors identified at the granule cells of the dentate gyrus and cerebellum, and the relay neurons of the thalamus, are distinct from the synaptic receptors. Extrasynaptic conductance can have a considerable influence on neuronal excitability (Leroy et al., 2004). Extrasynaptic receptors exhibit both a high GABA affinity and reduced receptor desensitization in the continued presence of the agonist (Fritschy and Brunig, 2003). Such properties render these receptors ideally suited to sense the low ambient concentrations $(\sim 0.5-1 \mu \mathrm{M})$ of the extrasynaptic neurotransmitters (Kennedy et al., 2002). Extrasynaptic receptors containing the $\delta$-subunit are highly sensitive to neurosteroids in certain brain region (Wohlfarth et al., 2002). At low "physiological” concentrations (10-100 nM), $3 \alpha 5 \alpha$-THDOC selectively enhance the tonic 
conductance, with little or no effect on the phasic conductance in mouse DGCs and CGCs (Stell et al., 2003; Belelli and Lambert, 2005; Farrant and Nusser, 2005). Tonic inhibition is reduced in the $\delta$-subunit "knockout" mice, and the residual tonic current was insensitive to $3 \alpha 5 \alpha$-THDOC (Mihalek et al., 1999; Stell et al., 2003). However, the extrasynaptic effects of neurosteroids also reveal regional difference in the CNS. Two hundred fifty nanomolar $3 \alpha 5 \alpha$-THDOC has no effect on the tonic inhibition in ventrobasalis complex of the thalamus (Porcello et al., 2003). On the other hand, the tonic conductance of hippocampal CA1 neurons expressing $\mathrm{GABA}_{\mathrm{A}}$-receptor with $\alpha_{5}$ subunit is affected by $3 \alpha 5 \alpha$-THDOC ( $\geq 100 \mathrm{nM}$; Stell et al., 2003; Belelli and Lambert, 2005; Farrant and Nusser, 2005). It is suggested that the modulation of tonic currents is influenced by local neurosteroid metabolism. The inhibition of metabolism can greatly enhance the response of the tonic current in dentate granule cells to endogenous neurosteroids, but not on the synthetic metabolically stable ganaxalone (Belelli and Herd, 2003). Neurosteroid metabolism reveals regional specificity that also contributes to the regional specificity of the tonic $\mathrm{GABA}_{\mathrm{A}}$-receptor mediated currents. In summary, evidence is emerging that the $\mathrm{GABA}_{\mathrm{A}}$ receptor mediated tonic conductance present in some neurons may have a considerable influence on neuronal signaling and network activity (Brickley et al., 2001; Hamann et al., 2002; Mitchell and Silver, 2003). The high sensitivity of neurosteroids in extrasynaptic receptor may represent an important target for neurosteroids.

\section{AGONIST NEUROSTEROIDS ON THE GABA A $^{-R E C E P T O R ~}$}

The structure-activity relationship of neurosteroid actions on the $\mathrm{GABA}_{\mathrm{A}}$-receptor has been summarized in a number of articles (Laubach et al., 1955; Gyermek et al., 1968; Gyermek and Soyka, 1975; Sear, 1997). The systemic investigation of several isomers of $\mathrm{GABA}_{\mathrm{A}}$-receptor active neurosteroids revealed a couple crucial structure variations (Figure 2), namely the geometry between ring $\mathrm{A} / \mathrm{B}$; a hydrogen-bond donator in $\mathrm{C} 3$ position; a hydrogen-bond acceptor in $\mathrm{C} 20$ position and/or a flexible bond at C17 position (Purdy et al., 1990; Zorumski et al., 2000; Ragagnin et al., 2007). The $\alpha$ - and $\beta$-configuration refer to constituents below and above the plane of the steroid backbone. Variation of the core and substitution in certain positions of the steroid molecules has crucial consequence on the neurosteroid effects (Figure 2).

Anesthetic steroids typically have a saturated backbone of four rings, although this is not an absolute requirement for activity. The four rings form a rigid framework for positioning the hydrogen bonding groups in three-dimensional spaces (Figure 2). The presence of hydrogen-bond donor in the $\alpha$-configuration at C3 and $\beta$-configuration at $\mathrm{C} 17$ are critical for the sedative action of agonist neurosteroids (Purdy et al., 1990; Hawkinson et al., 1994b; Hogenkamp et al., 1997). These groups are important for the binding of neurosteroids to a variety of proteins by means of hydrogenbinding with polar or charged residues (Brzozowski et al., 1997; Grishkovskaya et al., 2000). Replacing the hydrogen of hydroxyl with methyl, thus eliminating the ability of the steroid to donate a hydrogen bond in this region, results in dramatic reduction in its potency (Upasani et al., 1997). Replacing the steroid skeleton with an alicyclic framework like 2-cyclohexylideneperhydro-4,

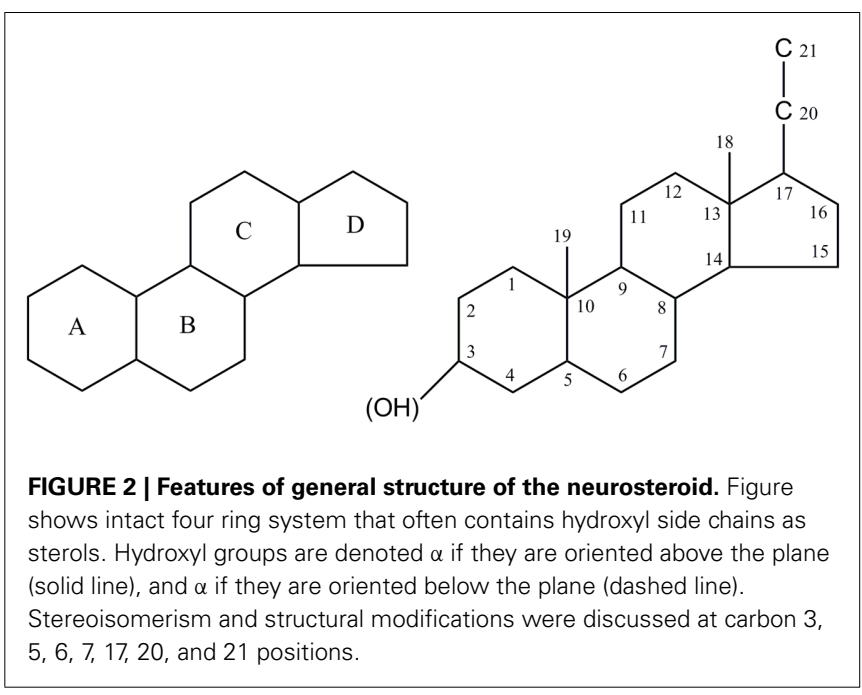

7-methanoindene derivatives give a compound that showed weak potentiating activity (Burden et al., 2000). When the carbonitrile is replaced with an acetyl group the derivatives become inactive (Hamilton, 2002).

The configuration of C5-reduction is important to potency. Even if steroids with either $5 \alpha$ or $5 \beta$ conformations are active, spatial difference in this position may affect the pharmacology of the neurosteroids. Allopregnanolone with $5 \alpha$-reduction is generally more potent than its $5 \beta$-isomer, pregnanolone, as $\mathrm{GABA}_{\mathrm{A}}$-receptor agonist both in vivo and in vitro. Studies with $3 \alpha 5 \alpha$-THDOC and its stereoisomer $3 \alpha 5 \beta$-THDOC revealed important differences in potency, efficacy, and regional selectivity at the $\mathrm{GABA}_{\mathrm{A}}$-receptor in favor of $5 \alpha$-reduction (Gee and Lan, 1991; Mennerick et al., 2004). $5 \alpha$-steroid, but not $5 \beta$-steroids, showed a high degree of enantioselectivity/enantiospecificity in their action as modulator of the $\mathrm{GABA}_{\mathrm{A}}$-receptor and as anesthetics (Covey et al., 2000). The efficacy of $3 \beta 5 \beta-P$ to inhibit $\mathrm{GABA}_{\mathrm{A}}$-receptor is significantly different from $3 \beta 5 \alpha-P$ (Rahman et al., 2006; Wang et al., 2007). 5 $\beta$-reduced antagonist neurosteroids cause significant higher inhibition than the $5 \alpha$-isomers.

Like pregnan steroids, metabolites of testosterone such as androstanediol are also modulators of GABA. It was found that the systemic $3 \alpha$-androstanediol administration conditions a place preference more effectively than does systemic administration of dihydrotestosterone or testosterone (Frye, 2001). Additionally, plasma concentration of $3 \alpha$-androstanediol is increased compare to dihydrotestosterone and testosterone. However, the potency and efficacy effect of $3 \alpha$-androstane steroid is lower than those of $3 \alpha$-pregnan steroids (Rahman et al., 2006).

\section{ANTAGONIST NEUROSTEROIDS ON THE GABA $A_{A}-$ RECEPTOR}

Neurosteroids may both enhance and inhibit GABAergic neurotransmission (Wang et al., 2002; Mennerick et al., 2004; Rahman et al., 2006; Stromberg et al., 2006). It has been shown earlier that $3 \beta$-hydroxy A-ring reduced pregnane steroids ( $3 \beta-\mathrm{OH}$ steroids) and pregnenolone sulfate inhibit $\mathrm{GABA}_{\mathrm{A}}$-receptor coupled anion channels (Wang et al., 2002, 2007; Lundgren et al., 2003; Birzniece et al., 2006b). 3 $\beta-O H$ steroids and PS, at concentrations that had 
little effect on GABAergic synaptic currents, significantly reversed the potentiating effect of $3 \alpha-\mathrm{OH}$ A-ring reduced steroids (Wang et al., 2002). Although antagonistic steroids reduced the potentiation induced by $3 \alpha-\mathrm{OH}$ steroids, they still acted non-competitively with respect to the agonistic steroids and inhibited a larger potentiation more efficiently (Wang et al., 2002). Furthermore, $3 \beta-O H$ steroids co-applied with GABA alone significantly inhibited GABA responses at concentrations $\geq \mathrm{EC}_{50}$ (Garrett and Gan, 1998; Maitra and Reynolds, 1998; Wang et al., 2002; Lundgren et al., 2003). This direct, non-competitive effect of $3 \beta-\mathrm{OH}$ steroids and PS on the GABA response was sufficient to account for the apparent antagonism of agonist steroids (Rahman et al., 2006). In summary, both PS and $3 \beta-O H$ steroids inhibited the $\mathrm{GABA}_{\mathrm{A}}$-receptor more effectively under conditions that promoted agonist binding or channel opening (Wang et al., 2002). The interaction between antagonist and agonist steroids was due to a use-dependent action of antagonist steroids at recombinant and synaptic $\mathrm{GABA}_{\mathrm{A}}$-receptors (Wang et al., 2002).

\section{MECHANISM OF PREGNENOLONE SULFATE AND NEUROSTEROID SULFATE ESTERS}

Sulfated steroids like pregnenolone sulfate and dehydroepiandrosterone sulfate can produce profound effects on behavior. PS as an abundant neurosteroid enhances learning (Mayo et al., 1993; Flood et al., 1995), and antagonizes the impairment of learning and memory produced by ethanol and scopolamine (Melchior and Ritzmann, 1996). PS may play a role in cognition and have been reported as negative modulators of the $\mathrm{GABA}_{\mathrm{A}}$-receptor based on electrophysiological studies and GABA-mediated ${ }^{36} \mathrm{Cl}^{-}$uptake by rat brain synaptosomes (Majewska et al., 1990; Demirgoren et al., 1991). Structure-activity relationships of $\mathrm{GABA}_{\mathrm{A}}$-receptor modulation are different for sulfated inhibitory steroids vs. non-sulfated potentiating steroids (Park-Chung et al., 1999). Potentiation by non-sulfated steroids requires $3 \alpha$-stereochemistry. Pregnenolone by itself is inactive on the $\mathrm{GABA}_{\mathrm{A}}$-receptor. In contrast, both $3 \alpha-$ and $3 \beta$-isomers of PS is inhibitory. Although the addition of a negatively charged sulfate group or hemisuccinate group at the $\mathrm{C} 3$ position converts the neurosteroid from being potentiating to inhibitory (Park-Chung et al., 1999), a negatively charged group at $\mathrm{C} 3$ is not absolutely essential for inhibition since the nonsulfated neurosteroid DHEA is also inhibitory. However, DHEA is less potent than its sulfated derivative DHEAS (Imamura and Prasad, 1998; Park-Chung et al., 1999). Steroids such as 11-keto derivative of PS are of particular interest, as it behaves as a positive, negative, or neutral modulator on the $\mathrm{GABA}_{\mathrm{A}}$-receptor. It is suggested that 11-keto pregnenolone sulfate (11-keto PS) exerts a dual action on distinct positive and negative steroid modulation sites associated with the $\mathrm{GABA}_{\mathrm{A}}$-receptor (Park-Chung et al., 1999).

Consistent with the idea that PS induces activation-dependent inhibition on the $\mathrm{GABA}_{\mathrm{A}}$-receptor (Wang et al., 2002), another report revealed that the inhibition of basal inhibitory postsynaptic currents (IPSCs) by antagonist steroids was correlated with the basal decay time of the IPSCs (Eisenman et al., 2003). Analysis of single-channel behavior in the presence of GABA and PS suggested no difference in the ability of PS to block liganded closed vs. liganded open receptors (Akk et al., 2001). These results leave open the possibility that PS may prefer liganded over unliganded receptors, consistent with a model of state-dependence to PS actions.

An earlier study observed that PS inhibits GABA-gated $\mathrm{Cl}^{-}$current by enhancing receptor desensitization and stabilizing desensitized state with prolonged application of low-affinity GABA agonists to nucleated membrane patched (Shen et al., 2000). Note that the promotion of desensitization is selective for prolonged GABA applications (Shen et al., 2000). It is well-known that the time course of GABA-mediated IPSCs is influenced strongly by the kinetics of the $\mathrm{GABA}_{\mathrm{A}}$-receptor desensitization (Celentano and Wong, 1994; Jones and Westbrook, 1995). Desensitized states are thought to buffer receptors in bound conformations that make it possible for channels to re-open before GABA unbinds. The fast phase of desensitization limits the open probability of the channels, influences peak synaptic currents, and contributes to the fast component of IPSC decay. The slow component of decay may result from reopening of GABA channels after exit from desensitized states (Jones and Westbrook, 1995). On the other hand, recombinant $\mathrm{GABA}_{\mathrm{A}}$-receptors composed of defined subunit combinations also give rise to currents with complex decay kinetics (Lavoie et al., 1997; Haas and Macdonald, 1999). In cultured hippocampal neurons, PS decreases the peak current of the inhibitory autapic currents, enhances the fast and slow phases of deactivation after brief application of a few milliseconds. After longer application ( $\sim 100 \mathrm{~ms}$ or more), PS enhances both the fast and slow phases of desensitization of the GABA current (Shen et al., 2000; Eisenman et al., 2003). Moreover, PS reduces the agonist steroid evoked prolongation of sIPSC and reduces channel-opening frequency (Mienville and Vicini, 1989). However, recording the sIPSC of neurons medial preoptic nucleus (MPN) shows that PS neither affects the peak amplitude nor the decay of sIPSC (Haage et al., 2005). Instead, PS reduces the frequency of the sIPSC at higher concentration (Haage et al., 2005). The main effect of PS on the sIPSC time course is explained by a simplified model that this substance reduce the rate of desensitization while the agonist steroids assumed to reduce the unbinding rate of GABA from the receptor (Haage et al., 2005).

\section{MECHANISM OF $3 \beta$-HYDROXYSTEROID AS GABA A $^{-R E C E P T O R ~}$ ANTAGONIST}

According to earlier studies, PS (Woodward et al., 1992), 3 $\beta$ $\mathrm{OH}$ steroids, or carboxylated steroids (Mennerick et al., 2001) are more effective against GABA responses gated by high concentrations of GABA. In electrophysiological studies, $3 \beta 5 \beta-\mathrm{P}$ antagonized the $3 \alpha 5 \beta-\mathrm{P}$ induced enhancement of GABA current (Maione et al., 1992; Maitra and Reynolds, 1998). On the other hand, $3 \beta 5 \alpha-\mathrm{P}$ diminished the inhibitory effects of $3 \alpha 5 \alpha$ $\mathrm{P}$ on population spikes evoked in rat hippocampal CA1 stratum pyramidal (Wang et al., 2000). Studies on the chloride uptake into synaptosomes in rat cerebral cortex, in hippocampus and sIPSC in MPN showed that $3 \beta-\mathrm{OH}$ steroids reduced the $3 \alpha 5 \alpha-\mathrm{P}$ enhanced GABA response (Stromberg et al., 2006). In the presence of low concentration GABA, some of the $3 \beta-\mathrm{OH}$ steroids potentiated GABA-evoked chloride ion uptake and prolonged the decay time, whereas the others had little or no effect on 
GABA stimulated current. Therefore, certain $3 \beta-\mathrm{OH}$ steroids, namely $5 \beta$-pregnane- $3 \beta, 20(\mathrm{~S})$-diol and $3 \beta-\mathrm{OH}-5 \beta$-pregnane-20one have both agonistic and antagonist property (Wang et al., 2002; Stromberg et al., 2006). Moreover, another study with the $\mathrm{Cl}^{-}$ uptake method has shown that $3 \beta-\mathrm{OH}-5 \alpha$-pregnan-20-one is a useful antagonist of $3 \alpha 5 \alpha$-P enhanced GABA response (Lundgren et al., 2003). However, in $\mathrm{GABA}_{\mathrm{A}}$-receptor expressed in Xenopus oocytes showed that $3 \beta$-steroids inhibit GABA response at near-saturating concentrations (Rahman et al., 2006). It is still unclear why the effect of $3 \beta-\mathrm{OH}$ steroids varies with different methods. It is likely that the steroid structure, drug application time and base line GABA concentration may be responsible for the discrepancy.

It is suggested that a homologous mutation of the residue at 2 'position closest to the cytoplasmic end of the M2 helix to serine on both the $\beta_{1}$ and the $\beta_{2}$ subunit, $\alpha_{1}$ V256S and $\beta_{2} \mathrm{~A} 252 \mathrm{~S}$, reduced the desensitization rate of GABA-activation at saturating doses (Wang et al., 2007). In a receptor complex with reduced desensitization components to GABA-activation (e.g., mutant receptors), the PS-inhibition was also greatly reduced (Akk et al., 2001). On the other hand, PS has been shown earlier to increase the deactivation rate of the GABA-evoked sIPSCs recorded by patchclamp techniques at the acutely dissociated neurons from the MPN area of the rat brain slice (Haage et al., 2005). Recent studies confirmed the findings that PS increased the fast offset rate of GABA-activation (Wang et al., 2007). However, the slow component of the offset time course was decreased by PS in a dose-dependent manner. The potencies of $5 \alpha$-pregnan-3 $\beta, 20 \alpha$ diol and $5 \beta$-pregnan-3 $\beta, 20 \beta$-diol to influence offset time courses of GABA-activation were significantly lower than PS, in accordance with our earlier findings while PS was significantly more potent to inhibit both peak and steady-state GABA currents than 3 $\beta$-OH steroids (Wang et al., 2002, 2006, 2007). PS-inhibition was already seen at low dose of GABA response $\left(\leq \mathrm{EC}_{20}\right.$; Eisenman et al., 2003), whereas the inhibition by $3 \beta-\mathrm{OH}$ steroids on the current response was first seen at higher end $\left(>\mathrm{EC}_{50}\right)$ of the GABA dose-response curve (Wang et al., 2002). Obviously, 5 $\alpha$-pregnan$3 \beta, 20 \alpha$-diol and $5 \beta$-pregnan-3 $\beta, 20 \beta$-diol prolonged the fast offset time course of GABA response, suggesting that the inherent association between $3 \beta-\mathrm{OH}$ steroids and receptor has rather high affinity. However, it was not fully excluded that a more complicated model of a multivalent interaction between hydrophobic steroids and receptor is employed. Kinetic properties of $3 \beta-\mathrm{OH}$ steroids have also been elucidated in acute dissociate neurons from the MPN area of the hypothalamus (Stromberg et al., 2006). These steroids have no effect on the activation phase or the maximum amplitude of $3 \alpha 5 \alpha-P$ enhanced IPSCs. They rather affect the slow deactivation phase. A recent report shows that $3 \beta-\mathrm{OH}$ steroids exert their effect by reducing the $3 \alpha 5 \alpha-\mathrm{P}$ induced prolongation of decay time constant $\left(\mathrm{t}_{\text {decay }}\right.$; Stromberg et al., 2006).

\section{DIFFERENTIAL MODULATION OF $\rho$ RECEPTOR CHANNELS BY NEUROSTEROIDS}

The $\rho_{1}$ GABA receptor is constitutes a dominant inhibitory force in the retina but is expressed at lower levels throughout the nervous system. Drugs acting on the $\rho_{1}$ receptor can be useful in the treatment of a variety of visual, sleep, and cognitive disorders.
Selective antagonists of $\rho$ receptors can prevent the development of myopia and enhance learning and memory in rats in the Morris water maze task after intraperitoneal injection (Chebib et al., 2009). Receptors containing the $\rho$ subunit have been implicated in apoptosis of hippocampal neurons (Yang et al., 2003) and regulation of hormone release in the pituitary gland (Boue-Grabot et al., 2000).

Several neurosteroids are shown to modulate the $\rho_{1}$ receptor channel. Allopregnanolone, $5 \alpha$-THDOC, and $5 \alpha$-pregnane$3 \alpha$-ol-11,20-dione (alphaxalone) potentiated the GABA-evoked currents from $\rho_{1}$ receptor channels and concomitantly altered the deactivation kinetics by prolonging the decay time. In contrast, pregnanolone, $5 \beta$-pregnane- 3,20 -dione $(5 \beta$ dihydroprogesterone), and 5 $\beta$-THDOC inhibited the GABAelicited currents of the $\rho_{1}$ receptor channel. In comparison to $\mathrm{GABA}_{\mathrm{A}}$-receptors, the modulation of $\rho_{1}$ receptor channels by neurosteroids occurred with relatively high concentrations and was more prominent in the presence of low concentrations of GABA. Structural comparison of these six neuroactive steroids reveals that the key parameter in determining the mode of modulation for the $\rho_{1}$ receptor channel is the position of the hydrogen atom bound to the fifth carbon, imposing a transor cis-configuration in the backbone structure (Morris et al., 1999).

A study focusing on the electrophysiological effects of inhibitory steroids on the $\rho_{1}$ receptor found that steroid inhibitors could be divided into three major groups based on how mutations to residues in the M2 transmembrane domain modified inhibition (Li et al., 2007). A recent study from the same research group (Li et al., 2010) selected representatives of the three groups (pregnanolone, tetrahydrodeoxycorticosterone, pregnanolone sulfate, allopregnanolone sulfate and $\beta$-estradiol) to probe how these steroids, as well as the non-steroidal inhibitor picrotoxinin, modify GABA-elicited fluorescence changes from the Alexa 546 C5 maleimide fluorophore attached to residues in the extracellular region of the $\mathrm{GABA}_{\mathrm{A}}$-receptor. The fluorophore responds with changes in quantum yield to changes in the environment, allowing it to probe for structural changes taking place during channel activation or modulation. The authors reported that the modulators have specific effects on fluorescence changes suggesting that distinct conformational changes accompany inhibition ( $\mathrm{Li}$ et al., 2010). Results are consistent with the steroids acting as allosteric inhibitors of the $\rho 1$ GABA receptor and support the hypothesis that divergent mechanisms underlie the action of inhibitory steroids on the $\rho 1 \mathrm{GABA}$ receptor.

\section{THE SITE OF NEUROSTEROID AGONIST ON THE GABA $_{A}-$ RECEPTOR}

Neurosteroids bind to $\mathrm{GABA}_{\mathrm{A}}$-receptors at a site that is distinct from the recognition sites for GABA, benzodiazepines, and barbiturates. This results in allosteric modulation of GABA binding or channel gating. The ability of neurosteroids to potentiate GABA-activated currents recorded from a variety of neurons indicated that most isoforms of the $\mathrm{GABA}_{\mathrm{A}}$-receptor should be capable of binding neurosteroid modulators (Mitchell et al., 2008). This concept was supported by studies of recombinant $\mathrm{GABA}_{\mathrm{A}}$ receptors with differing subunit composition that revealed a wide 
spectrum of activity for neurosteroids at $\mathrm{GABA}_{\mathrm{A}}$-receptors with some minor variations in efficacy (Puia et al., 1993; Lambert et al., 1996; Maitra and Reynolds, 1999; Belelli et al., 2002). Neurosteroid modulation lacking subunit selectivity suggested that neurosteroids are binding to a site that is conserved throughout most members of the $\mathrm{GABA}_{\mathrm{A}}$-receptor family.

Studies using $\mathrm{GABA}_{\mathrm{A}}$ /glycine-receptor chimeras suggested an allosteric action of neuroactive steroids at the $\mathrm{N}$-terminal side of the middle of the second transmembrane domain (M2) of the $\mathrm{GABA}_{\mathrm{A}}$-receptor $\beta_{1}$ and/or $\alpha_{2}$ subunits (Rick et al., 1998). Electrophysiological studies have confirmed that neurosteroid agonists enhance $\mathrm{Cl}^{-}$-currents by increasing both channel frequency and channel open duration at $\mathrm{GABA}_{\mathrm{A}}$-receptor (Callachan et al., 1987; Puia et al., 1990; Zhu and Vicini, 1997). Neurosteroid agonists do not require direct aqueous access to the receptor, and membrane accumulation is required for receptor modulation (Akk et al., 2005). Hosie et al. (2006) identified two discrete binding sites in the receptor's transmembrane domains that mediate the potentiating and direct activation effects of neurosteroid agonists at the $\mathrm{GABA}_{\mathrm{A}}$-receptor. The potentiating effect of $3 \alpha 5 \alpha$-THDOC is mediated by a cavity formed by the $\alpha$ subunit transmembrane domains. On the other hand, the direct activation of $\mathrm{GABA}_{\mathrm{A}}$-receptor by $3 \alpha 5 \alpha$-THDOC is mediated by interfacial residues between $\alpha$ and $\beta$-subunits, and is enhanced by steroid binding to the potentiation site (Hosie et al., 2006). These profiles indicate that two distinct neuroactive steroid binding sites may exist; $\alpha$ THr236 and $\beta$ Tyr284 residues in the transmembrane domain initiate direct activation whereas $\alpha \mathrm{G} \ln 241$ and $\alpha$ Asn 407 mediate the potentiating response (Hosie et al., 2006). The neurosteroid potentiation site was further identified in the $\alpha_{1} \beta_{2} \gamma_{2 S}$ receptor by mutation of Q241 to methionine or leucine, which reduced the potentiation of GABA currents by the naturally occurring neurosteroids, allopregnanolone, or tetrahydrodeoxycorticosterone (THDOC; Hosie et al., 2006, 2007).

In order to address whether the potentiation site for neurosteroids on $\mathrm{GABA}_{\mathrm{A}}$-receptors is conserved amongst different $\mathrm{GABA}_{\mathrm{A}}$-receptor isoforms, Hosie et al. (2006) used chimera to generate 100 models based on an alignment of the transmembrane domains of the $\mathrm{GABA}_{\mathrm{A}}$-receptor $\alpha_{1}$ subunit and the $\mathrm{nACh}$ receptor $\alpha$ chain and selecting the 10 best models, revealed that the potentiation site is associated only with the a subunit and the activation site is interfacial between the $\alpha$ - and $\beta$-subunit.

By using heterologous expression of $\mathrm{GABA}_{\mathrm{A}}$-receptors in $\mathrm{HEK}$ cells, in combination with whole-cell patch-clamp recording methods, a relatively consistent potentiation by allopregnanolone of GABA-activated currents was evident for receptors composed of one a subunit isoform $\left(\alpha_{2-5}\right)$ assembled with $\beta_{3}$ and $\gamma_{2 s}$ subunits (Hosie et al., 2009). By introducing mutant $\alpha \beta \gamma$ receptors, the neurosteroid potentiation was dependent on the conserved glutamine residue in $\mathrm{M} 1$ of the respective a subunit (Hosie et al., 2009). Studying wild-type and mutant receptors composed of $\alpha_{4} \beta_{3} \delta$ subunits revealed that the $d$ subunit is unlikely to contribute to the neurosteroid potentiation binding site and probably affects the efficacy of potentiation (Hosie et al., 2009).

In summary, the neurosteroid potentiation site was likely contained entirely within or on the transmembrane domains of the $\alpha$-subunit. The importance of this site for neurosteroid binding was also confirmed by the functional data on mutant $\alpha_{1}$ subunit that reduced the potentiation of GABA responses by many synthetic steroids at $\alpha_{1} \beta_{2} \gamma_{2 L}$ receptors (Akk et al., 2008; Li et al., 2009).

\section{THE SITE OF NEUROSTEROID ANTAGONIST ON THE GABA $_{A}-$ RECEPTOR}

It is generally accepted that the sulfate moiety is critical in producing a steroid that blocks rather than potentiates $\mathrm{GABA}_{\mathrm{A}}$ receptors (Park-Chung et al., 1999). The fact that an anionic group is critical gave suggestion to us that the sulfate might actually interact with residues forming the binding site mediating antagonism. However, no voltage dependency was observed with pregnenolone sulfate-inhibition on the GABA response (Majewska and Schwartz, 1987; Majewska et al., 1988; Akk et al., 2001), which suggests that the charged sulfate moiety does not interact significantly with the membrane field as PS approaches the transition state between unbound and unblocked to bound and blocked (Woodhull, 1973). Therefore, the lack of voltage dependence of pregnenolone sulfate-inhibition suggests that it is unlikely that the sulfate moiety interacts with a site deep within the channel (Akk et al., 2001). Results from our earlier report suggest that pregnenolone sulfate was a $\gamma_{2}$-subunit independent inhibitor at $\mathrm{GABA}_{\mathrm{A}}$-receptors (Wang et al., 2006). However, residues deep in the channel at the $2^{\prime}$ position in the M2 helix of both $\alpha_{1}$ and $\gamma_{2}$-subunit were critical for pregnenolone sulfate-inhibition (Akk et al., 2001; Wang et al., 2002, 2006). Theoretically, a large, rigid molecule such as a steroid would bind end-on rather than with its long axis across the channel. It is thus possible that either the A-ring (where the sulfate moiety is attached) or the D-ring (the other end of the molecule) would penetrate the $\mathrm{Cl}^{-}$ channel most deeply. The lack of voltage dependence indicates that the A-ring is unlikely to penetrate to the $2^{\prime}$ position. The structure of the D-ring of PS is identical to that for many $3 \beta$ hydroxysteroids. Since the inhibitory properties of $5 \alpha$-pregnan$3 \beta, 20 \alpha$-diol and $5 \beta$-pregnan-3 $\beta, 20 \beta$-diol were also reduced in the $\alpha_{1 \mathrm{M}} \beta_{2} \gamma_{2 \mathrm{~L}}$ receptor, we think it is more likely that the uncharged portions of the steroid molecules interact with the $2^{\prime}$ residue closest to the cytoplasmic end of the M2 helix on the $\alpha_{1}$ subunit.

The site of action of sulfated neuroactive steroids on $\mathrm{GABA}_{\mathrm{A}}$ receptors remains unclear. Based upon the observation that PS reduced the apparent affinity of $\left[{ }^{35} \mathrm{~S}\right]$-TBPS, Sousa and Ticku (1997) suggested that PS and DHEAS might bind at the picrotoxin/cage convulsant site. However, a mutation to the transmembrane M2 channel domain eliminated picrotoxin sensitivity but the inhibitory effects of PS and DHEAS persisted (Shen et al., 1999; Gibbs et al., 2006). The absence of voltage sensitivity or alteration of single-channel open time argues against a binding site within the pore. Akk et al. (2001) identified a valine residue in the channel domain of the $\alpha_{1}$ subunit that slowed the development of PS-inhibition when mutated to serine, but concluded that this residue is unlikely to be part of the binding site and likely influences PS action indirectly (Akk et al., 2001). Using homologous mutation of the residue at $2^{\prime}$ position closest to the cytoplasmic end of the M2 helix to serine on both $\alpha_{1}$ and $\beta_{2}$ 
subunit, namely $\alpha_{1} \mathrm{~V} 256 \mathrm{~S}$ and $\beta_{2} \mathrm{~A} 252 \mathrm{~S}$, it was found that effect of PS is greatly reduced in these two mutant (Akk et al., 2001; Wang et al., 2006, 2007). This suggests that these two amino acids are involved in the PS mediated inhibition. However, it is unclear whether these specific mutations at the cytoplasmic end of M2 helix exert their effect by altering the allosteric mechanism or by directly altering a binding site. A recent study in $C$. elegans identified multiple residues in transmembrane domain 1 (M1), as well as a residue near the extracellular end of the M2 helix, that are critical for low-micromolar inhibition of C. elegans $\mathrm{GABA}_{\mathrm{A}}$-receptors by PS (Wardell et al., 2006). This latter residue is of particular interest, as it is a positively charged arginine that could potentially coordinate with the negatively charged sulfate of PS. The C. elegans receptor exhibits some pharmacological differences as compared to mammalian $\mathrm{GABA}_{\mathrm{A}}$-receptors (for example, pregnanolone is inhibitory). So, these results may or may not be relevant to mammalian receptors; however, it is notable that an arginine residue is also found in this region of mammalian $\mathrm{GABA}_{\mathrm{A}}$-receptor subunits (Gibbs et al., 2006; Wardell et al., 2006).

Block of responses to high-efficacy agonists by this sulfated steroid is greater than block of responses to partial agonists at saturating concentrations. This is called "activation dependant" or "state dependant inhibition" (Wang et al., 2002; Eisenman et al., 2003). Picrotoxin, another GABA channel blocker superficially similar to pregnenolone sulfate in its activation dependence but the site of action of PS does not require a functional picrotoxin site for inhibition of GABA responses (Shen et al., 1999). The GABA receptor antagonist $\mathrm{Zn}^{2+}$ also acts in activation dependant manner. However, the $\mathrm{Zn}^{2+}$ binding site is located in the interface between the $\alpha$ - and $\beta$-subunit and $\mathrm{Zn}^{2+}$ activity is minimal in ternary $\alpha \beta \gamma$ receptor (Hosie et al., 2003).

\section{GABA-STEROIDS AND THE MOOD CHANGE}

Mood disorders are common health problems affecting women, especially during fertile ages. It is suggested that periods of hormonal variability, i.e., menarche (Angold et al., 1999), premenstrual periods (Soares et al., 2001), postpartum (Kendell et al., 1981; Chaudron et al., 2001), and perimenopause (Freeman et al., 2004) increase the risk of mood disorders in certain women. There are three obvious examples in interaction between mood, steroids, and CNS, namely PMDD, side effects of oral contraceptives and negative mood symptoms encountered during sequential progestagen addition to estrogen treatment in postmenopausal women.

An obvious relation between sex steroids and mood changes are cyclic symptoms related to the menstrual cycle. Estradiol and progesterone display regular predictable changes during the menstrual cycle. In parallel with the increase of progesterone, an increase also occur in serum concentrations of allopregnanolone and pregnanolone (Wang et al., 1996). Although allopregnanolone is synthesized in the brain, the major source to its brain concentration is the corpus luteum of the ovary (Bixo et al., 1997; Ottander et al., 2005). Allopregnanolone and progesterone are produced in parallel at the luteal phase of menstrual cycle (Wang et al., 1996; Genazzani et al., 1998). In fertile women plasma levels of allopregnanolone are approximately $0.2-0.5 \mathrm{nmol} / \mathrm{L}$ in the follicular phase and up to $4 \mathrm{nmol} / \mathrm{L}$ in the luteal phase. In the third trimester of a pregnancy, serum concentrations of allopregnanolone can increase to more than $100 \mathrm{nmol} / \mathrm{L}$ (Bicikova et al., 1995; Luisi et al., 2000). Pregnanolone displays a similar pattern with increase in the luteal phase (Wang et al., 1996; Sundstrom et al., 1998).

GABA-steroids are positive modulators of GABA responses on the $\mathrm{GABA}_{\mathrm{A}}$-receptor (Majewska et al., 1986). Chemically they are $3 \alpha$-hydroxy- $5 \alpha / \beta$ metabolites of progesterone (pregnanolone and allopregnanolone), testosterone ( $3 \alpha 5 \alpha$-androstandiol), and desoxycorticosterone (tetrahydro-desoxycorticosterone, THDOC). GABA-steroids enhance the GABA effect on chloride flux resulting in increased inhibition of neural activity (Majewska et al., 1986; Gee et al., 1987; Birzniece et al., 2006b). GABAsteroids induce sedation and can be used as anesthetic drugs in human (Carl et al., 1990; Timby et al., 2006). GABA-steroids are anti-epileptic (Backstrom et al., 1984; Landgren et al., 1987) and in animal experiments they also possess an anxiolytic effect similar to benzodiazepines (Wieland et al., 1991). An anxiolytic effect of allopregnanolone has, however, never been shown in humans.

Human and animal studies revealed typical $\mathrm{GABA}_{\mathrm{A}}$-receptor agonistic effects of allopregnanolone and pregnanolone at high doses, i.e., sedation/anesthesia (Carl et al., 1990; Timby et al., 2006), anti-epileptic effects (Landgren et al., 1998), and anxiolytic effects in animals (Wieland et al., 1991). However, earlier reports from human and animal models also indicated that all $\mathrm{GABA}_{\mathrm{A}}-$ receptor agonists could induce negative symptoms with anxiety, irritability/aggressiveness in certain individuals. Strong irritability/aggression was induced in 3-6\% of individuals and moderate symptoms are induced in 20-30\% (Masia et al., 2000; Weinbroum et al., 2001). Interestingly, the prevalence of PMDD among women in reproductive age was in the similar range of $3-8 \%$. The corresponding prevalence of PMS, with milder symptom severity than PMDD, was $25-35 \%$ of women in reproductive age (Sveindottir and Backstrom, 2000).

It is puzzling why an increase in allopregnanolone during the menstrual cycle is related to development of negative mood as allopregnanolone should be anxiolytic agent like benzodiazepines. The answer depends on the fact that all $\mathrm{GABA}_{\mathrm{A}}$ receptor agonists such as benzodiazepines, barbiturates, alcohol, and allopregnanolone have paradoxical anxiogenic effects in certain individuals. At low concentrations or doses they give severe adverse emotional reactions in a subset of individuals $(3-6 \%)$ and moderate reactions in up to $20-30 \%$ of individuals. This paradoxical effect is induced by allopregnanolone (Beauchamp et al., 2000; Miczek et al., 2003) benzodiazepines (Ben-Porath and Taylor, 2002), barbiturates (Lee et al., 1988; Kurthen et al., 1991; Weinbroum et al., 2001), and ethanol (Cherek et al., 1992; Dougherty et al., 1996; Miczek et al., 2003). Symptoms induced by these $\mathrm{GABA}_{\mathrm{A}}$-receptor active drugs are depressive mood, irritability, aggression, and other symptoms known to occur during the luteal phase in women with PMS/PMDD. A biphasic effect was also observed for medroxyprogesterone (MPA) and natural progesterone in postmenopausal women taking hormone therapy. These women felt worse on a lower dosage of MPA or progesterone than on a 
higher dosage or placebo (Bjorn et al., 2002; Andreen et al., 2005, 2006).

Thus allopregnanolone seems to have a biphasic effect on mood with an inverted U-shaped relationship between concentration and effect. In postmenopausal women receiving progesterone, a biphasic relation between the negative mood symptoms and the plasma concentrations of allopregnanolone was observed. The negative mood increased with the elevating serum concentration of allopregnanolone up to the maximum concentration seen at the luteal phase. With further increase in allopregnanolone concentration there was a decrease in symptom severity (Andreen et al., 2005, 2006). An inverted U-shaped relation between allopregnanolone dosage and irritability/aggression has also been noted in rats (Miczek et al., 2003).

\section{POSSIBLE EXPLANATIONS FOR THE PARADOXICAL EFFECT OF GABA-STEROIDS}

In this section, possible mechanisms of the biphasic response curve of allopregnanolone on behavioral parameters are discussed. The basic idea of so called paradoxical effect where neurosteroids show one type of effect at low concentrations and another type at high concentrations is that an enhanced $\mathrm{GABA}_{\mathrm{A}}$-receptor activity may give an excitatory net effect in certain situations, instead of the usual inhibitory effect (Backstrom et al., 2011). The following hypotheses suggest several possible mechanisms how this can be achieved. In addition, there are no contradictions between the different hypothesis and they may very well act in parallel.

One explanation is based on that inhibitory neurons are the most sensitive to GABA-steroids and therefore are the first to be inhibited at elevated steroid concentrations. This will give a release of the inhibitory tone at excitatory neurons, a so called disinhibition. The idea emphasizes that specific combination of subunits determines the receptor sensitivity to neurosteroids (Belelli et al., 2002; Stromberg et al., 2006). In this context, extrasynaptic $\mathrm{GABA}_{\mathrm{A}}$-receptors containing the $\delta$-subunit are of interest because they seem to be more sensitive to GABA-steroids than other types of subunit combinations (Mody, 2008). A possibility exists that one type of inhibitory neurons contains $\mathrm{GABA}_{\mathrm{A}}$ receptors with the $\delta$-subunit, while the next in order contains another subunit, making them less sensitive to GABA-steroids. It has also been reported that the receptor subunit composition and sensitivity to GABA-modulators can be regulated by environmental factors such as stress (Biggio et al., 1990; Concas et al., 1996).

Another idea is based on the finding that GABA-evoked currents at receptors with the $\alpha_{4} \beta_{2} \delta$ combination are actually inhibited, instead of potentiated, by allopregnanolone (Shen et al., 2007). During stress allopregnanolone and other GABA-steroids are produced and give an anxiolytic effect (Bitran et al., 1999). However, Smith and colleagues showed that female mice reacted with increased anxiety to stress during puberty (Shen et al., 2007). In humans, puberty is often a period characterized by mood swings and anxiety. This research group revealed that allopregnanolone changed from being a positive modulator of the $\mathrm{GABA}_{\mathrm{A}}$ receptor, at the time before and after puberty, to become a negative modulator at the time of puberty (Shen et al., 2007). They also reported that the change in effect coincide with an higher expression of the $\alpha_{4} \beta_{2} \delta$ subunit combination (Shen et al., 2007). The $\mathrm{GABA}_{\mathrm{A}}$-receptor subunit combination that contains the $\delta$-subunit was known to be very sensitive to GABA-steroids, and is activated by lower concentrations of allopregnanolone than other receptor subtypes (Wohlfarth et al., 2002; Liang et al., 2004). Therefore, the action of allopregnanolone at the $\alpha_{4} \beta_{2} \delta$ receptor provides a mechanism for the generation of negative mood at puberty. The proposed hypothesis requires a higher number or proportion of $\mathrm{GABA}_{\mathrm{A}}$-receptors with the type(s) that are inhibited by steroids also in other conditions when paradoxical steroid effects are seen (PMDD/PMS). Actually, the $\alpha_{4} \beta \delta$ subunit composition was a key factor in the progesterone withdrawal model for PMDD (Gallo and Smith, 1993; Smith et al., 1998).

A third hypothesis is that the paradoxical effect arises when the $\mathrm{Cl}^{-}$gradient across the membrane of critical neurons favors an excitatory rather than inhibitory effect of $\mathrm{GABA}_{\mathrm{A}}$-receptor activation. The $\mathrm{Cl}^{-}$gradient across the cell membrane is subject to active regulation and may also vary between different types of neurons as well as between different compartments within the neuron. In adult vertebrate neurons, the intracellular $\mathrm{Cl}^{-}$concentration was usually relatively low and, the $\mathrm{GABA}_{\mathrm{A}}$-receptor activation inhibited neuronal impulse activity. In contrast, during fetal and early postnatal development, the intracellular $\mathrm{Cl}^{-}$concentration was comparably high, and thus the $\mathrm{GABA}_{\mathrm{A}}$-receptor activation caused an excitation (Kahle et al., 2008). The intracellular $\mathrm{Cl}^{-}$ concentration is determined not only by passive flux through the $\mathrm{GABA}_{\mathrm{A}}$-receptor and other $\mathrm{Cl}^{-}$-permeable channels, but also by cation- $\mathrm{Cl}^{-}$-cotransporters, with the major inward transport often mediated by NKCC1 and the major outward transport by KCC2 (Price et al., 2005, 2009; De Koninck, 2007). In adults, the outward transport mediated by KCC2 dominates, which keeps the intracellular $\mathrm{Cl}^{-}$concentration low.

However, the intracellular $\mathrm{Cl}^{-}$concentration may be higher also in the adult brain, which has been demonstrated for the axon initial segment of cortical neurons (Szabadics et al., 2006; Khirug et al., 2008) and certain types of neurons in amygdala (Martina et al., 2001) and substantia nigra (Gulacsi et al., 2003), as well as in gonadotropin-releasing hormone neurons (Moenter and DeFazio, 2005) and in presynaptic terminals (Haage et al., 2002). Interestingly, estradiol was one factor that increased the activity of NKCC1 under normal physiological conditions and thus increased the intracellular $\mathrm{Cl}^{-}$concentration (Nakamura et al., 2004; Galanopoulou, 2008). Intriguingly, estradiol dose dependently increased the mood provoking effect of progestagens in women (Bjorn et al., 2003), and negative mood effects in women with PMDD/PMS (Dhar and Murphy, 1990).

Finally, would it be possible to explain the inverted bell shaped relationship between $\mathrm{GABA}_{\mathrm{A}}$-receptor active steroid concentrations and symptoms that has been reported from clinical studies? The report of Prescott et al. (2006) suggested that at a slightly more positive $\mathrm{Cl}^{-}$equilibrium potential, a moderate increase in GABAergic activity gave an increased excitation, whereas a larger GABAergic activity gave the opposite effect. However, whether an altered intracellular $\mathrm{Cl}^{-}$concentration in adulthood may explain the paradoxical effect of $\mathrm{GABA}_{\mathrm{A}}$-receptor modulators remains to be proven. 


\section{THE ROLE OF NEUROSTEROIDS IN BEHAVIORAL DISORDERS}

A number of review articles have discussed the important role of neurosteroids in treating behavioral disorders by interacting with the $\mathrm{GABA}_{\mathrm{A}}$-receptor (Majewska, 1992; Reddy and Kulkarni, 2000; Zorumski et al., 2000; Rupprecht et al., 2001). There are a few obstacles preventing the clinical use of endogenous neurosteroids. First of all, naturally occurring neurosteroids such as allopregnanolone have low bioavailability because they are rapidly inactivated and eliminated by glucoronide or sulfate conjugation at the $3 \alpha$-hydroxy group. The second obstacle is that the $3 \alpha$-hydroxy group of allopregnanolone may undergo oxidation to a ketone, restoring its activity at nuclear hormone receptors

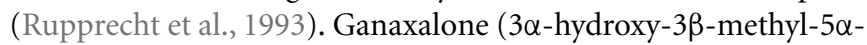
pregnane-20-one), the $3 \beta$-methyl analog of allopregnanolone, is an example of synthetic neurosteroid that overcomes these limitations (Carter et al., 1997). Like allopregnanolone, ganaxalone is a positive allosteric modulator of $\mathrm{GABA}_{\mathrm{A}}$-receptor (Carter et al., 1997).

Neurosteroids modulate anxiety and stress level. After an acute stress stimulus, release of progesterone, pregnenolone, allopregnanolone, and $3 \alpha 5 \alpha$-THDOC occur in the blood circulation (Purdy et al., 1992; Barbaccia et al., 1998; Serra et al., 2000). Allopregnanolone and $3 \alpha 5 \alpha$-THDOC have potent anxiolytic activity in several animal anxiety models (Crawley et al., 1986; Bitran et al., 1995; Wieland et al., 1995; Reddy and Kulkarni, 2000). However, the anxiolytic effect of allopregnanolone has not been shown in human (Wihlback et al., 2006). Recent reports indicated that allopregnanolone can induce aggression and anxiety at low concentrations (Fish et al., 2001; Gulinello et al., 2001; Miczek et al., 2003). Allopregnanolone and cortisol levels are increased during the examination of $\mathrm{PhD}$ students (Droogleever Fortuyn et al., 2004). Therefore, it is suggested that allopregnanolone has biphasic effects in certain individuals (Miczek et al., 2003). At low doses it has an adverse, anxiogenic effect. This effect decreases with increasing doses of allopregnanolone and the beneficial and calming property occurs (Beauchamp et al., 2000; Fish et al., 2001). A major concern with potential new anxiolytics is whether they suffer the same drawbacks as classical benzodiazepines. Using the elevated plus-maze paradigm for assessing the anxiolytic activity, selective effects of neurosteroids have been reported which differ from diazepam (Rodgers and Johnson, 1998). Synthetic derivative Co 2-6749 30, which retains a $3 \beta$-trifluoromethyl group that should block metabolism and enhance oral bioavailability, is selected for clinical development because there is a large separation between anxiolytic effects and side effects (Gasior et al., 1999; Vanover et al., 2000). Women with PMDD show often difficulties in concentration and develop fatigue during the luteal phase of the menstrual cycle, which is associated with high circulating levels of allopregnanolone (Sundstro and Backstrom, 1999).

Enzymes involving the production of allopregnanolone are present in the hippocampus (Compagnone and Mellon, 2000). Using the Morris water maze paradigm, allopregnanolone was found to inhibit learning (Johansson et al., 2002). Antagonist neurosteroid $3 \beta, 20 \beta$-dihydroxy- $5 \alpha$-pregnane (UC1011), reduced the negative effect of allopregnanolone on learning in the Morris water maze (Turkmen et al., 2004). PS infused into the basal magnocellular nucleus enhanced memory performance, whereas allopregnanolone disrupted memory (Mayo et al., 1993). Pregnenolone, DHEA, and DHEAS increased memory when injected systemically, centrally or into the amygdala (Flood et al., 1988, 1992; Wolkowitz et al., 1995). There was evidence that the concentrations of DHEA and DHEAS decreased in patients suffering from AD (Sunderland et al., 1989; Nasman et al., 1991; Hillen et al., 2000). It is promising that certain neurosteroids should be further explored in the context of prevention and treatment of Alzheimer's disease and mild cognitive impairment.

\section{GABA-STEROIDS AND COGNITIVE FUNCTIONS}

Chronic stress, stress-steroids, and sex steroids are linked to the development of dementia (Shumaker et al., 2003; Lupien et al., 2005; Sandstrom et al., 2005). In women taking postmenopausal hormone therapy by administration of medroxyprogesterone, a GABA-steroid precursor, the risk for dementia, and AD doubled after 5 years of treatment (Shumaker et al., 2003). Medroxyprogesterone can induce anesthesia by acting on the $\mathrm{GABA}_{\mathrm{A}}$-receptor (Meyerson, 1967). On the other hand, estrogen has been claimed to protect against dementia (Henderson et al., 1994). This was, however, not confirmed in the large Women's Health Initiative (WHI) study but estrogen by itself did not increase the risk to develop dementia (Shumaker et al., 2004). Hormone therapy with medroxyprogesterone resembles the exposure to stress-steroids during chronic stress. $\mathrm{GABA}_{\mathrm{A}}$-receptor agonists are known to impair memory. Allopregnanolone can inhibit learning in rats tested in Morris water maze, an accepted test model for learning and memory (Johansson et al., 2002). It is well-known that most $\mathrm{GABA}_{\mathrm{A}}$-receptor agonists, e.g., benzodiazepines (Barker et al., 2004), barbiturates (Mohammed et al., 1987), and alcohol (Saunders et al., 1991; Vincze et al., 2007) impair memory and learning and increase the risk for permanent damages, although the risk with low and moderate alcohol consumption is under debate (Solfrizzi et al., 2007).

The brain and serum concentrations of GABA-steroids vary with the production of adrenals, ovaries, and testicles (Purdy et al., 1991; Wang et al., 1996; Bixo et al., 1997; Luisi et al., 2000). Interestingly, classical stress hormones, cortisol, and corticosterone, metabolized in a similar way and allotetrahydrocortisol (Allo-THF, $3 \alpha$-hydroxy-5 $\alpha$-cortisol) interacts also with the $\mathrm{GABA}_{\mathrm{A}}$-receptor (Celotti et al., 1992). Allo-THF enhances the inhibitory effect of allopregnanolone and has synergic effect on neuronal inhibition together with allopregnanolone (Stromberg et al., 2005). That is why neurons are exposed to a stronger inhibition during acute and chronic stress. During acute stress, allopregnanolone and THDOC increase in the brain of normal animals. In animals subjected to chronic long-term stress, allopregnanolone concentrations decreased in cortex at rest. However, a larger increase of allopregnanolone was observed in cortex after acute stress in this group of animals than normal controls (Serra et al., 2000). Patients with AD show an increased glucocorticoid production compared to healthy elderly control subjects. In addition, an increased $5 \alpha$-reduction was seen in patients with AD. Thus an increased glucocorticoid production can be regarded as an early feature of $\mathrm{AD}$ since an enhanced production of $5 \alpha$-reduced metabolites of cortisol was established 
(Rasmuson et al., 2001). $3 \alpha-\mathrm{OH}-5 \alpha$-reduced metabolites of cortisol interact with the $\mathrm{GABA}_{\mathrm{A}}$-receptor and enhance the effect of GABA-steroids on the $\mathrm{GABA}_{\mathrm{A}}$-receptor (Stromberg et al., 2005).

Chronic stress can impair memory (de Quervain et al., 1998). Memory impairment is permanent in persons with a chronically elevated adrenal production of GABA-steroids (Lupien et al., 2005). Memory impairment was also reported in chronic stress syndromes, so called "burn-out syndrome." "Burn-out syndrome" occurs frequent in patients with $\mathrm{AD}$. The production of cortisol and GABA-steroids increased in parallel during stress (Purdy et al., 1991; Serra et al., 2003; Droogleever Fortuyn et al., 2004). During chronic stress, long-term exposure to $\mathrm{GABA}_{\mathrm{A}}$-receptor agonist results in similar changes after prolonged exposure to benzodiazepine and alcohol. Long-term and enhanced activation of the $\mathrm{GABA}_{\mathrm{A}}$-receptor is an important factor in of memory impairment during stress. The response of cortisol and GABAsteroids to adrenal stimulation was similar in patients with $\mathrm{AD}$ as chronically stressed animals (Nasman et al., 1991, 1996). Patients with mild Alzheimer's disease have a high and nonsuppressible production of cortisol and GABA-steroids (Nasman et al., 1995).

After long-term exposure to GABA-steroids, down-regulation of the GABA $_{A}$-receptor is expected (Yu and Ticku, 1995b; Barnes, 1996). A malfunctioned $\mathrm{GABA}_{\mathrm{A}}$-receptor can be an important factor in the pathogenesis of stress-induced depression, "burnout" syndrome and sex-steroid related depression (Drugan et al., 1989; Wihlback et al., 2006). The down-regulation occurs at different levels in a time dependent manner: (i) desensitization; (ii) receptor internalization; (iii) receptor subunit degradation; (iv) altered expression of receptor mRNA (Barnes, 1996). Exposure to an agonist of the $\mathrm{GABA}_{\mathrm{A}}$-receptor may cause changes in receptor mRNA and induce changes of the $\mathrm{GABA}_{\mathrm{A}}$-receptor subunit composition (Smith et al., 1998). In women with PMDD, reduced benzodiazepine, ethanol, and GABA-steroid sensitivities occur in the luteal phase, but not in the follicular phase of the menstrual cycle (Sundstrom et al., 1997, 1998; Nyberg et al., 2004). In rodents, repeated administrations of GABA-steroids caused tolerance development (Birzniece et al., 2006a) in terms of GABAsteroid-induced inhibition on learning (Turkmen et al., 2006). It is well-known that prolonged exposure to allopregnanolone altered the function of $\alpha_{4}$ subunit and $\alpha_{1}$ subunit (Smith et al., 1998). In fact, the $\alpha_{4} \beta_{2} \gamma_{2}$ receptor is less sensitive to steroid modulation than the $\alpha_{1} \beta_{2} \gamma_{2}$ receptor (Belelli et al., 2002). In an earlier study on tolerance development in rats, acute tolerance against allopregnanolone-induced anesthesia developed after $90 \mathrm{~min}$ of exposure and change in $\mathrm{GABA}_{\mathrm{A}}$-receptor $\alpha_{4}$ subunit expression was observed in thalamus (Birzniece et al., 2006a).

\section{ALLOPREGNANOLONE AND SUPPRESSED HPA AXIS STRESS RESPONSES IN LATE PREGNANCY OF RAT}

In late pregnancy, hypothalamo-pituitary-adrenal (HPA) axis responses to stressful stimuli are suppressed (Brunton and Russell, 2003). Up-regulated opioid peptide produced by nucleus tractus solitarii (NTS) neurons acts presynaptically on noradrenergic terminals in the paraventricular nucleus (PVN) to inhibit noradrenaline release in response to interleukin-1 $\beta$ (IL-1 $\beta$ ) in late pregnancy (Brunton et al., 2009). Allopregnanolone signals the pregnancy status of the animal to the brain and stimulates opioid production in the brainstem. Allopregnanolone also act via $\mathrm{GABA}_{\mathrm{A}}$-receptors to enhance GABA action in the PVN. In rat, allopregnanolone concentration increase greatly in both the circulation and the brain in pregnancy and reach a peak on day 19-20 of pregnancy (Concas et al., 1998; Brunton et al., 2009). Parvocellular corticotropin-releasing hormone $(\mathrm{CRH})$ neurons in the PVN are under direct inhibitory GABAergic control (Miklos and Kovacs, 2002). 5 $\alpha$-reductase activity is increased in the hypothalamus in late pregnancy (Brunton et al., 2009), suggesting that the capacity to produce allopregnanolone is increased in pregnancy. Allopregnanolone may act locally to enhance GABA action in the PVN or on inputs to the CRH neurons to attenuate HPA axis responses to stress in late pregnancy. The importance of allopregnanolone to inhibit HPA axis responses to stress in later pregnancy has been tested by blocking its production using a $5 \alpha \mathrm{R}$ inhibitor, finasteride (FIN). Blocking allopregnanolone generation with finasteride (FIN) at a dose shown to reduce brain allopregnanolone content by up to 90\% (Concas et al., 1998), substantially restores HPA axis responses to systemically administered IL-1 $\beta$ in late pregnant rats (Brunton et al., 2009). AP appears to depend upon the actions of endogenous opioids to exert its suppressive effects on HPA axis activity (Brunton et al., 2009). Allopregnanolone induces opioid tone (as revealed by naloxone treatment) over ACTH responses to immune challenge in virgin rats (Brunton et al., 2009). Induction of inhibitory opioid tone over HPA axis responses to IL- $1 \beta$ by AP treatment occurs within $20 \mathrm{~h}$, consistent with the rapid increase in pENK-A mRNA expression in the NTS that has been seen after IL-1 $\beta$ treatment (Engstrom et al., 2003). The mechanism by which AP upregulates opioid expression in the NTS is not clear. However, interaction with $\mathrm{GABA}_{\mathrm{A}}$-receptors is a possibility (Blyth et al., 2000) as has been described for $\mathrm{CRH}$ and vasopressin gene expression in the PVN (Bali and Kovacs, 2003) and for hypothalamic oxytocin gene expression at the end of pregnancy (Blyth et al., 2000). It is possible that allopregnanolone-induced opioid tone represents a global mechanism through which HPA axis responses to other stressful stimuli are restrained in late pregnancy. This pregnancy adaptation is expected to protect the fetuses from adverse early life programming by maternal glucocorticoids, although this protection is obviously incomplete (Brunton and Russell, 2010, 2011). Withdrawal of these mechanisms or failure to maintain them appropriately might predispose the fetuses to disease in later life (Welberg and Seckl, 2001).

\section{ACKNOWLEDGMENTS}

The author thank Torbjörn Bäckström and David Haage for advices and critical reading of an early version of the manuscript. This work was supported by the Swedish Research Councilmedicine (project 73p-15450), Insamlingsstiftelsen för medicinsk forskning vid Umeå Universitet, Svenska läkaresällskapets forskare program, ALF medel from västerbottens lans landsting, Magn. Bergvalls Stiftelse and the EU regional fund's objective 1 program. 


\section{REFERENCES}

Adkins, C. E., Pillai, G. V., Kerby, J., Bonnert, T. P., Haldon, C., McKernan, R. M., Gonzalez, J. E., Oades, K., Whiting, P. J., and Simpson, P. B. (2001). alpha4beta3delta GABA(A) receptors characterized by fluorescence resonance energy transfer-derived measurements of membrane potential. J. Biol. Chem. 276, 38934-38939.

Akk, G., Bracamontes, J., and Steinbach, J. H. (2001). Pregnenolone sulfate block of $\mathrm{GABA}(\mathrm{A})$ receptors: mechanism and involvement of a residue in the M2 region of the alpha subunit. J. Physiol. (Lond.) 532, 673-684.

Akk, G., Li, P., Bracamontes, J., Reichert, D. E., Covey, D. F., and Steinbach, J. H. (2008). Mutations of the GABA-A receptor alphal subunit M1 domain reveal unexpected complexity for modulation by neuroactive steroids. Mol. Pharmacol. 74, 614-627.

Akk, G., Shu, H. J., Wang, C., Steinbach, J. H., Zorumski, C. F., Covey, D. F., and Mennerick, S. (2005). Neurosteroid access to the GABAA receptor. J. Neurosci. 25, 11605-11613.

Amin, J., and Weiss, D. S. (1994). Homomeric rho 1 GABA channels: activation properties and domains. Recept. Channels 2, 227-236.

Amin, J., and Weiss, D. S. (1996). Insights into the activation mechanism of rhol GABA receptors obtained by coexpression of wild type and activation-impaired subunits. Proc. Biol. Sci. 263, 273-282.

Andreen, L., Sundstrom-Poromaa, I., Bixo, M., Andersson, A., Nyberg, S., and Backstrom, T. (2005). Relationship between allopregnanolone and negative mood in postmenopausal women taking sequential hormone replacement therapy with vaginal progesterone. Psychoneuroendocrinology 30, 212-224.

Andreen, L., Sundstrom-Poromaa, I., Bixo, M., Nyberg, S., and Backstrom, T. (2006). Allopregnanolone concentration and mood - a bimodal association in postmenopausal women treated with oral progesterone. Psychopharmacology (Berl.) 187, 209-221.

Angold, A., Costello, E. J., Erkanli, A., and Worthman, C. M. (1999). Pubertal changes in hormone levels and depression in girls. Psychol. Med. 29, 1043-1053.

Backstrom, T. (1976). Epilepsy in women. Oestrogen and progesterone plasma levels. Experientia 32, 248-249.

Backstrom, T., Andreen, L., Birzniece, V., Bjorn, I., Johansson, I. M., Nordenstam-Haghjo, M., Nyberg, S., Sundstrom-Poromaa, I., Wahlstrom,
G., Wang, M., and Zhu, D. (2003). The role of hormones and hormonal treatments in premenstrual syndrome. CNS Drugs 17, 325-342.

Backstrom, T., Gee, K. W., Lan, N., Sorensen, M., and Wahlstrom, G. (1990). Steroids in relation to epilepsy and anaesthesia. Ciba Found. Symp. 153, 225-230; discussion 230-239.

Backstrom, T., Haage, D., Lofgren, M., Johansson, I. M., Stromberg, J., Nyberg, S., Andreen, L., Ossewaarde, L., Wingen, G. A., Turkmen, S., and Bengtsson, S. K. (2011). Paradoxical effects of GABA-A modulators may explain sex steroid induced negative mood symptoms in some persons. Neuroscience 191, 46-54.

Backstrom, T., Zetterlund, B., Blom, S., and Romano, M. (1984). Effects of intravenous progesterone infusions on the epileptic discharge frequency in women with partial epilepsy. Acta Neurol. Scand. 69, 240-248.

Bai, D., Zhu, G., Pennefather, P., Jackson, M. F., MacDonald, J. F., and Orser, B. A. (2001). Distinct functional and pharmacological properties of tonic and quantal inhibitory postsynaptic currents mediated by gammaaminobutyric acid(A) receptors in hippocampal neurons. Mol. Pharmacol. 59, 814-824.

Bali, B., and Kovacs, K. J. (2003). GABAergic control of neuropeptide gene expression in parvocellular neurons of the hypothalamic paraventricular nucleus. Eur. J. Neurosci. 18, 1518-1526.

Banerjee, P. K., and Snead, O. C. III. (1998). Neuroactive steroids exacerbate gamma-hydroxybutyric acidinduced absence seizures in rats. Eur. J. Pharmacol. 359, 41-48.

Barbaccia, M. L., Concas, A., Serra, M., and Biggio, G. (1998). Stress and neurosteroids in adult and aged rats. Exp. Gerontol. 33, 697-712.

Barker, M. J., Greenwood, K. M., Jackson, M., and Crowe, S. F. (2004). Persistence of cognitive effects after withdrawal from long-term benzodiazepine use: a meta-analysis. Arch. Clin. Neuropsychol. 19, 437-454.

Barnes, E. M. Jr. (1996). Use-dependent regulation of GABAA receptors. Int. Rev. Neurobiol. 39, 53-76.

Baulieu, E. E., and Robel, P. (1995). Non-genomic mechanisms of action of steroid hormones. Ciba Found. Symp. 191, 24-37; discussion 37-42.

Baulieu, E. E., Robel, P., and Schumacher, M. (2007). Neurosteroids: beginning of the story. Int. Rev. Neurobiol. 46, 1-32.

Beauchamp, M. H., Ormerod, B. K., Jhamandas, K., Boegman, R. J., and Beninger, R. J. (2000). Neurosteroids and reward: allopregnanolone produces a conditioned place aversion in rats. Pharmacol. Biochem. Behav. 67, 29-35.

Belelli, D., Casula, A., Ling, A., and Lambert, J. J. (2002). The influence of subunit composition on the interaction of neurosteroids with GABA(A) receptors. Neuropharmacology 43, 651-661.

Belelli, D., and Herd, M. B. (2003). The contraceptive agent Provera enhances GABA(A) receptor-mediated inhibitory neurotransmission in the rat hippocampus: evidence for endogenous neurosteroids? J. Neurosci. 23, 10013-10020.

Belelli, D., Herd, M. B., Mitchell, E. A., Peden, D. R., Vardy, A. W., Gentet, L., and Lambert, J. J. (2006). Neuroactive steroids and inhibitory neurotransmission: mechanisms of action and physiological relevance. Neuroscience 138, 821-829.

Belelli, D., and Lambert, J. J. (2005). Neurosteroids: endogenous regulators of the GABA(A) receptor. Nat. Rev. Neurosci. 6, 565-575.

Ben-Porath, D. D., and Taylor, S. P. (2002). The effects of diazepam (valium) and aggressive disposition on human aggression: an experimental investigation. Addict. Behav. 27, 167-177.

Bicikova, M., Lapcik, O., Hampl, R., Starka, L., Knuppen, R., Haupt, O., and Dibbelt, L. (1995). A novel radioimmunoassay of allopregnanolone. Steroids 60, 210-213.

Biggio, G., Concas, A., Corda, M. G., Giorgi, O., Sanna, E., and Serra, M. (1990). GABAergic and dopaminergic transmission in the rat cerebral cortex: effect of stress, anxiolytic and anxiogenic drugs. Pharmacol. Ther. 48, 121-142.

Birzniece, V., Turkmen, S., Lindblad, C., Zhu, D., Johansson, I. M. Backstrom, T., and Wahlstrom, G. (2006a). GABA(A) receptor changes in acute allopregnanolone tolerance. Eur. J. Pharmacol. 535, 125-134.

Birzniece, V., Backstrom, T., Johansson, I. M., Lindblad, C., Lundgren, P., Lofgren, M., Olsson, T., Ragagnin, G., Taube, M., Turkmen, S., Wahlstrom, G., Wang, M. D., Wihlback, A. C., and Zhu, D. (2006b). Neuroactive steroid effects on cognitive functions with a focus on the serotonin and GABA systems. Brain Res. Brain Res. Rev. 51, 212-239.

Bitran, D., Dugan, M., Renda, P., Ellis, R., and Foley, M. (1999). Anxiolytic effects of the neuroactive steroid pregnanolone ( 3 alpha-OH-5 betapregnan-20-one) after microinjection in the dorsal hippocampus and lateral septum. Brain Res. 850, 217-224.

Bitran, D., Shiekh, M., and McLeod, M. (1995). Anxiolytic effect of progesterone is mediated by the neurosteroid allopregnanolone at brain GABAA receptors. J. Neuroendocrinol. 7, 171-177.

Bixo, M., Andersson, A., Winblad, B., Purdy, R. H., and Backstrom, T. (1997). Progesterone, 5alpha-pregnane-3,20-dione and 3alpha-hydroxy-5alpha-pregnane-

20-one in specific regions of the human female brain in different endocrine states. Brain Res. 764, 173-178.

Bjorn, I., Bixo, M., Nojd, K. S., Collberg, P., Nyberg, S., SundstromPoromaa, I., and Backstrom, T. (2002). The impact of different doses of medroxyprogesterone acetate on mood symptoms in sequential hormonal therapy. Gynecol. Endocrinol. $16,1-8$.

Bjorn, I., Sundstrom-Poromaa, I., Bixo, M., Nyberg, S., Backstrom, G., and Backstrom, T. (2003). Increase of estrogen dose deteriorates mood during progestin phase in sequential hormonal therapy. J. Clin. Endocrinol. Metab. 88, 2026-2030.

Blyth, B. J., Hauger, R. L., Purdy, R. H., and Amico, J. A. (2000). The neurosteroid allopregnanolone modulates oxytocin expression in the hypothalamic paraventricular nucleus. Am. J. Physiol. Regul. Integr. Comp. Physiol. 278 R684-R691.

Bormann, J. (2000). The 'ABC' of GABA receptors. Trends Pharmacol. Sci. 21, 16-19.

Boue-Grabot, E., Taupignon, A., Tramu, G., and Garret, M. (2000). Molecular and electrophysiological evidence for a GABAc receptor in thyrotropin-secreting cells. Endocrinology 141, 1627-1632.

Brickley, S. G., Cull-Candy, S. G., and Farrant, M. (1996). Development of a tonic form of synaptic inhibition in rat cerebellar granule cells resulting from persistent activation of GABAA receptors. J. Physiol. (Lond.) 497(Pt 3), 753-759.

Brickley, S. G., Cull-Candy, S. G., and Farrant, M. (1999). Single-channel properties of synaptic and extrasynaptic GABAA receptors suggest differential targeting of receptor subtypes. J. Neurosci. 19, 2960-2973.

Brickley, S. G., Farrant, M., Swanson, G. T., and Cull-Candy, S. G (2001). CNQX increases GABAmediated synaptic transmission in the cerebellum by an AMPA/kainate receptor-independent mechanism. Neuropharmacology 41, 730-736. 
Brown, N., Kerby, J., Bonnert, T. P., Whiting, P. J., and Wafford, K. A. (2002). Pharmacological characterization of a novel cell line expressing human alpha(4)beta(3)delta GABA(A) receptors. Br. J. Pharmacol. 136, 965-974.

Brunton, P. J., McKay, A. J., Ochedalski, T., Piastowska, A., Rebas, E., Lachowicz, A., and Russell, J. A. (2009). Central opioid inhibition of neuroendocrine stress responses in pregnancy in the rat is induced by the neurosteroid allopregnanolone. J. Neurosci. 29, 6449-6460.

Brunton, P. J., and Russell, J. A. (2003). Hypothalamic-pituitary-adrenal responses to centrally administered orexin-A are suppressed in pregnant rats. J. Neuroendocrinol. 15, 633-637.

Brunton, P. J., and Russell, J. A. (2010). Prenatal social stress in the rat programmes neuroendocrine and behavioural responses to stress in the adult offspring: sex-specific effects. $J$. Neuroendocrinol. 22, 258-271.

Brunton, P. J., and Russell, J. A. (2011). Allopregnanolone and suppressed hypothalamo-pituitary-adrenal axis stress responses in late pregnancy in the rat. Stress 14, 6-12.

Brussaard, A. B., Kits, K. S., Baker, R. E., Willems, W. P., Leyting-Vermeulen, J. W., Voorn, P., Smit, A. B., Bicknell, R. J., and Herbison, A. E. (1997). Plasticity in fast synaptic inhibition of adult oxytocin neurons caused by switch in $\mathrm{GABA}(\mathrm{A})$ receptor subunit expression. Neuron 19, 1103-1114.

Brzozowski, A. M., Pike, A. C., Dauter, Z., Hubbard, R. E., Bonn, T. Engstrom, O., Ohman, L., Greene, G. L., Gustafsson, J. A., and Carlquist, M. (1997). Molecular basis of agonism and antagonism in the oestrogen receptor. Nature 389, 753-758.

Burden, P. M., Ai, T. H., Lin, H. Q., Akinci, M., Costandi, M., Hambley, T. M., and Johnston, G. A. (2000). Chiral derivatives of 2-cyclohexylideneperhydro-4,7methanoindenes, a novel class of nonsteroidal androgen receptor ligand: synthesis, X-ray analysis, and biological activity. J. Med. Chem. 43, 4629-4635.

Burgard, E. C., Tietz, E. I., Neelands, T. R., and Macdonald, R. L. (1996). Properties of recombinant gammaaminobutyric acid A receptor isoforms containing the alpha 5 subunit subtype. Mol. Pharmacol. 50, 119-127.

Callachan, H., Cottrell, G. A., Hather, N. Y., Lambert, J. J., Nooney, J. M., and Peters, J. A. (1987). Modulation of the GABAA receptor by progesterone metabolites. Proc. R. Soc. Lond. B Biol. Sci. 231, 359-369.
Caraiscos, V. B., Elliott, E. M., YouTen, K. E., Cheng, V. Y., Belelli, D., Newell, J. G., Jackson, M. F., Lambert, J. J., Rosahl, T. W., Wafford, K. A., MacDonald, J. F., and Orser, B. A. (2004). Tonic inhibition in mouse hippocampal CA1 pyramidal neurons is mediated by alpha5 subunit-containing gammaaminobutyric acid type A receptors. Proc. Natl. Acad. Sci. U.S.A. 101, 3662-3667.

Carl, P., Hogskilde, S., Nielsen, J. W., Sorensen, M. B., Lindholm, M. Karlen, B., and Backstrom, T. (1990). Pregnanolone emulsion. A preliminary pharmacokinetic and pharmacodynamic study of a new intravenous anaesthetic agent. Anaesthesia 45, 189-197.

Carter, R. B., Wood, P. L., Wieland, S., Hawkinson, J. E., Belelli, D., Lambert, J. J., White, H. S., Wolf, H. H., Mirsadeghi, S., Tahir, S. H., Bolger, M. B., Lan, N. C., and Gee, K. W. (1997). Characterization of the anticonvulsant properties of ganaxolone (CCD 1042; 3alpha-hydroxy-3betamethyl-5alpha-pregnan-20-one), a selective, high-affinity, steroid modulator of the gamma-aminobutyric acid(A) receptor. J. Pharmacol. Exp. Ther. 280, 1284-1295.

Casula, M. A., Bromidge, F. A., Pillai, G. V., Wingrove, P. B., Martin, K., Maubach, K., Seabrook, G. R., Whiting, P. J., and Hadingham, K. L. (2001). Identification of amino acid residues responsible for the alpha5 subunit binding selectivity of L655,708 , a benzodiazepine binding site ligand at the $\mathrm{GABA}(\mathrm{A})$ receptor. J. Neurochem. 77, 445-451.

Celentano, J. J., and Wong, R. K. (1994). Multiphasic desensitization of the GABAA receptor in outside-out patches. Biophys. J. 66, 1039-1050.

Celotti, F., Melcangi, R. C., and Martini, L. (1992). The 5 alpha-reductase in the brain: molecular aspects and relation to brain function. Front. Neuroendocrinol. 13, 163-215.

Chaudron, L. H., Klein, M. H., Remington, P., Palta, M., Allen, C., and Essex, M. J. (2001). Predictors, prodromes and incidence of postpartum depression. J. Psychosom. Obstet. Gynaecol. 22, 103-112.

Chebib, M., Hinton, T., Schmid, K. L., Brinkworth, D., Qian, H., Matos, S., Kim, H. L., Abdel-Halim, H., Kumar, R. J., Johnston, G. A., and Hanrahan, J. R. (2009). Novel, potent, and selective GABAC antagonists inhibit myopia development and facilitate learning and memory. J. Pharmacol. Exp. Ther. 328, 448-457.

Cheney, D. L., Uzunov, D., Costa, E., and Guidotti, A. (1995). Gas chromatographic-mass fragmentographic quantitation of 3 alpha-hydroxy-5 alpha-pregnan20-one (allopregnanolone) and its precursors in blood and brain of adrenalectomized and castrated rats. J. Neurosci. 15, 4641-4650.

Cherek, D. R., Spiga, R., and Egli, M. (1992). Effects of response requirement and alcohol on human aggressive responding. J. Exp. Anal. Behav. 58, 577-587.

Collinson, N., Kuenzi, F. M., Jarolimek, W., Maubach, K. A., Cothliff, R. Sur, C., Smith, A., Out, F. M. Howell, O., Atack, J. R., McKernan, R. M., Seabrook, G. R., Dawson, G. R., Whiting, P. J., and Rosahl, T. W. (2002). Enhanced learning and memory and altered GABAergic synaptic transmission in mice lacking the alpha 5 subunit of the GABAA receptor. J. Neurosci. 22, 5572-5580.

Compagnone, N. A., and Mellon, S. H. (2000). Neurosteroids: biosynthesis and function of these novel neuromodulators. Front. Neuroendocrinol. 21, 1-56.

Concas, A., Follesa, P., Barbaccia, M. L., Purdy, R. H., and Biggio, G. (1999). Physiological modulation of $\operatorname{GABA}(\mathrm{A})$ receptor plasticity by progesterone metabolites. Eur. J. Pharmacol. 375, 225-235.

Concas, A., Mostallino, M. C., Perra, C., Lener, R., Roscetti, G., Barbaccia, M. L., Purdy, R. H., and Biggio, G. (1996). Functional correlation between allopregnanolone and [35S]-TBPS binding in the brain of rats exposed to isoniazid, pentylenetetrazol or stress. $\mathrm{Br}$. J. Pharmacol. 118, 839-846.

Concas, A., Mostallino, M. C., Porcu, P., Follesa, P., Barbaccia, M. L., Trabucchi, M., Purdy, R. H., Grisenti, P. and Biggio, G. (1998). Role of brain allopregnanolone in the plasticity of gamma-aminobutyric acid type A receptor in rat brain during pregnancy and after delivery. Proc. Natl. Acad. Sci. U.S.A. 95, 13284-13289.

Cooper, E. J., Johnston, G. A., and Edwards, F. A. (1999). Effects of a naturally occurring neurosteroid on GABAA IPSCs during development in rat hippocampal or cerebellar slices. J. Physiol. (Lond.) 521(Pt 2), 437-449.

Cope, D. W., Hughes, S. W., and Crunelli, V. (2005). GABAA receptor-mediated tonic inhibition in thalamic neurons. J. Neurosci. 25, 11553-11563.

Corpechot, C., Young, J., Calvel, M. Wehrey, C., Veltz, J. N., Touyer, G., Mouren, M., Prasad, V. V., Banner, C., and Sjovall, J. (1993). Neurosteroids: 3 alpha-hydroxy-5 alphapregnan-20-one and its precursors in the brain, plasma, and steroidogenic glands of male and female rats. Endocrinology 133, 1003-1009.

Covey, D. F., Han, M., Kumar, A. S., de La Cruz, M. A., Meadows, E. S., Hu, Y., Tonnies, A., Nathan, D., Coleman, M., Benz, A., Evers, A. S., Zorumski, C. F., and Mennerick, S. (2000). Neurosteroid analogues. 8. Structure-activity studies of $\mathrm{N}$-acylated 17a-azaD-homosteroid analogues of the anesthetic steroids (3alpha, 5alpha)- and (3alpha,5beta)-3hydroxypregnan-20-one. J. Med. Chem. 43, 3201-3204.

Crawley, J. N., Glowa, J. R., Majewska, M. D., and Paul, S. M. (1986). Anxiolytic activity of an endogenous adrenal steroid. Brain Res. 398, 382-385.

Crestani, F., Keist, R., Fritschy, J. M., Benke, D., Vogt, K., Prut, L., Bluthmann, H., Mohler, H., and Rudolph, U. (2002). Trace fear conditioning involves hippocampal alpha5 GABA(A) receptors. Proc. Natl. Acad. Sci. U.S.A. 99, 8980-8985.

Crestani, F., Lorez, M., Baer, K., Essrich, C., Benke, D., Laurent, J. P., Belzung, C., Fritschy, J. M., Luscher, B., and Mohler, H. (1999). Decreased GABAA-receptor clustering results in enhanced anxiety and a bias for threat cues. Nat. Neurosci. 2, 833-839.

Davies, P. A., Hanna, M. C., Hales, T. G., and Kirkness, E. F. (1997). Insensitivity to anaesthetic agents conferred by a class of $\mathrm{GABA}(\mathrm{A})$ receptor subunit. Nature 385, 820-823.

De Koninck, Y. (2007). Altered chloride homeostasis in neurological disorders: a new target. Curr. Opin. Pharmacol. 7, 93-99.

de Quervain, D. J., Roozendaal, B., and McGaugh, J. L. (1998). Stress and glucocorticoids impair retrieval of long-term spatial memory. Nature 394, 787-790.

Demirgoren, S., Majewska, M. D., Spivak, C. E., and London, E. D. (1991) Receptor binding and electrophysiological effects of dehydroepiandrosterone sulfate, an antagonist of the GABAA receptor. Neuroscience 45, 127-135.

Devor, A., Fritschy, J. M., and Yarom, Y. (2001). Spatial distribution and subunit composition of GABA(A) receptors in the inferior olivary nucleus. J. Neurophysiol. 85, 1686-1696.

Dhar, V., and Murphy, B. E. (1990). Double-blind randomized crossover trial of luteal phase estrogens (Premarin) in the premenstrual syndrome (PMS). Psychoneuroendocrinology 15, 489-493. 
Do Rego, J. L., Seong, J. Y., Burel, D., Leprince, J., Luu-The, V., Tsutsui, K., Tonon, M. C., Pelletier, G., and Vaudry, H. (2009). Neurosteroid biosynthesis: enzymatic pathways and neuroendocrine regulation by neurotransmitters and neuropeptides. Front. Neuroendocrinol. 30, 259-301.

Dougherty, D. M., Cherek, D. R., and Bennett, R. H. (1996). The effects of alcohol on the aggressive responding of women. J. Stud. Alcohol 57, 178-186.

Drasbek, K. R., and Jensen, K. (2006). THIP, a hypnotic and antinociceptive drug, enhances an extrasynaptic GABAA receptor-mediated conductance in mouse neocortex. Cereb. Cortex 16, 1134-1141.

Droogleever Fortuyn, H. A., van Broekhoven, F., Span, P. N., Backstrom, T., Zitman, F. G., and Verkes, R. J. (2004). Effects of PhD examination stress on allopregnanolone and cortisol plasma levels and peripheral benzodiazepine receptor density. Psychoneuroendocrinology 29, 1341-1344.

Drugan, R. C., Morrow, A. L., Weizman, R., Weizman, A., Deutsch, S. I., Crawley, J. N., and Paul, S. M. (1989). Stress-induced behavioral depression in the rat is associated with a decrease in GABA receptormediated chloride ion flux and brain benzodiazepine receptor occupancy. Brain Res. 487, 45-51.

Edwards, H. E., Vimal, S., and Burnham, W. M. (2005). The acute anticonvulsant effects of deoxycorticosterone in developing rats: role of metabolites and mineralocorticoid-receptor responses. Epilepsia 46, 1888-1897.

Eisenman, L. N., He, Y., Fields, C., Zorumski, C. F., and Mennerick, S. (2003). Activation dependent properties of pregnenolone sulfate inhibition of GABAA receptor-mediated current. J. Physiol. 550, 679-691.

Engstrom, L., Engblom, D., and Blomqvist, A. (2003). Systemic immune challenge induces preproenkephalin gene transcription in distinct autonomic structures of the rat brain. J. Comp. Neurol. 462, 450-461.

Essrich, C., Lorez, M., Benson, J. A., Fritschy, J. M., and Luscher, B. (1998). Postsynaptic clustering of major GABAA receptor subtypes requires the gamma 2 subunit and gephyrin. Nat. Neurosci. 1, 563-571.

Farrant, M., and Nusser, Z. (2005). Variations on an inhibitory theme: phasic and tonic activation of GABA(A) receptors. Nat. Rev. Neurosci. 6, 215-229.

Farrar, S. J., Whiting, P. J., Bonnert, T. P., and McKernan, R. M. (1999).
Stoichiometry of a ligand-gatedion channel determined by fluorescence energy transfer. J. Biol. Chem. 274, 10100-10104.

Fish, E. W., Faccidomo, S., DeBold, J. F., and Miczek, K. A. (2001). Alcohol, allopregnanolone and aggression in mice. Psychopharmacology (Berl.) 153, 473-483.

Fisher, J. L., and Macdonald, R. L. (1997). Single channel properties of recombinant GABAA receptors containing gamma 2 or delta subtypes expressed with alpha 1 and beta 3 subtypes in mouse L929 cells. J. Physiol. 505(Pt 2), 283-297.

Flood, J. F., Morley, J. E., and Roberts, E. (1992). Memory-enhancing effects in male mice of pregnenolone and steroids metabolically derived from it. Proc. Natl. Acad. Sci. U.S.A. 89, 1567-1571.

Flood, J. F., Morley, J. E., and Roberts, E. (1995). Pregnenolone sulfate enhances post-training memory processes when injected in very low doses into limbic system structures: the amygdala is by far the most sensitive. Proc. Natl. Acad. Sci. U.S.A. 92, 10806-10810.

Flood, J. F., Smith, G. E., and Roberts, E. (1988). Dehydroepiandrosterone and its sulfate enhance memory retention in mice. Brain Res. 447 269-278.

Follesa, P., Concas, A., Porcu, P., Sanna, E., Serra, M., Mostallino, M. C., Purdy, R. H., and Biggio, G. (2001). Role of allopregnanolone in regulation of GABA(A) receptor plasticity during long-term exposure to and withdrawal from progesterone. Brain Res. Brain Res. Rev. 37, 81-90.

Follesa, P., Floris, S., Tuligi, G., Mostallino, M. C., Concas, A., and Biggio, G. (1998). Molecular and functional adaptation of the GABA(A) receptor complex during pregnancy and after delivery in the rat brain. Eur. J. Neurosci. 10, 2905-2912.

Fortin, D., Adams, R., and Gallez, A. (2004). A blood-brain barrier disruption model eliminating the hemodynamic effect of ketamine. Can. J. Neurol. Sci. 31, 248-253.

Freeman, E. W., Sammel, M. D., Liu, L., Gracia, C. R., Nelson, D. B., and Hollander, L. (2004). Hormones and menopausal status as predictors of depression in women in transition to menopause. Arch. Gen. Psychiatry $61,62-70$.

Fritschy, J. M., and Brunig, I. (2003). Formation and plasticity of GABAergic synapses: physiological mechanisms and pathophysiological implications. Pharmacol. Ther. 98, 299-323.
Frye, C. A. (2001). The role of neurosteroids and non-genomic effects of progestins and androgens in mediating sexual receptivity of rodents. Brain Res. Brain Res. Rev. 37, 201-222.

Frye, C. A., Mermelstein, P. G., and DeBold, J. F. (1992). Evidence for a non-genomic action of progestins on sexual receptivity in hamster ventral tegmental area but not hypothalamus. Brain Res. 578, 87-93.

Frye, C. A., Van Keuren, K. R., and Erskine, M. S. (1996). Behavioral effects of 3 alpha-androstanediol. I: modulation of sexual receptivity and promotion of GABA-stimulated chloride flux. Behav. Brain Res. 79, 109-118.

Galanopoulou, A. S. (2008). Sexually dimorphic expression of KCC2 and GABA function. Epilepsy Res. 80, 99-113.

Gallo, M. A., and Smith, S. S. (1993). Progesterone withdrawal decreases latency to and increases duration of electrified prod burial: a possible rat model of PMS anxiety. Pharmacol. Biochem. Behav. 46, 897-904.

Garrett, K. M., and Gan, J. (1998). Enhancement of gammaaminobutyric acidA receptor activity by alpha-chloralose. $J$. Pharmacol. Exp. Ther. 285, 680-686.

Gasior, M., Carter, R. B., and Witkin, J. M. (1999). Neuroactive steroids: potential therapeutic use in neurological and psychiatric disorders. Trends Pharmacol. Sci. 20, 107-112.

Gee, K. W., Chang, W. C., Brinton, R. E. and McEwen, B. S. (1987). GABAdependent modulation of the $\mathrm{Cl}$ ionophore by steroids in rat brain. Eur. J. Pharmacol. 136, 419-423.

Gee, K. W., and Lan, N. C. (1991). Gamma-aminobutyric acidA receptor complexes in rat frontal cortex and spinal cord show differential responses to steroid modulation. Mol. Pharmacol. 40, 995-999.

Genazzani, A. R., Petraglia, F., Bernardi, F., Casarosa, E., Salvestroni, C., Tonetti, A., Nappi, R. E., Luisi, S. Palumbo, M., Purdy, R. H., and Luisi, M. (1998). Circulating levels of allopregnanolone in humans: gender, age, and endocrine influences. J. Clin. Endocrinol. Metab. 83 , 2099-2103.

Gibbs, T. T., Russek, S. J., and Farb, D. H. (2006). Sulfated steroids as endogenous neuromodulators. Pharmacol. Biochem. Behav. 84, 555-567.

Glykys, J., Mann, E. O., and Mody, I. (2008). Which GABA(A) receptor subunits are necessary for tonic inhibition in the hippocampus? $J$. Neurosci. 28, 1421-1426.

Glykys, J., and Mody, I. (2006). Hippocampal network hyperactivity after selective reduction of tonic inhibition in GABA A receptor alpha5 subunit-deficient mice. $J$. Neurophysiol. 95, 2796-2807.

Glykys, J., and Mody, I. (2007). The main source of ambient GABA responsible for tonic inhibition in the mouse hippocampus. J. Physiol. (Lond.) 582, 1163-1178.

Grishkovskaya, I., Avvakumov, G. V., Sklenar, G., Dales, D., Hammond, G. L., and Muller, Y. A. (2000). Crystal structure of human sex hormonebinding globulin: steroid transport by a laminin G-like domain. $E M B O$ J. 19, 504-512.

Grobin, A. C., and Morrow, A. L. (2000). 3alpha-hydroxy-5alphapregnan-20-one exposure reduces GABA(A) receptor alpha4 subunit mRNA levels. Eur. J. Pharmacol. 409, R1-R2.

Grunewald, R. A., Aliberti, V., and Panayiotopoulos, C. P. (1992). Exacerbation of typical absence seizures by progesterone. Seizure 1, 137-138.

Gulacsi, A., Lee, C. R., Sik, A., Viitanen, T., Kaila, K., Tepper, J. M., and Freund, T. F. (2003). Cell type-specific differences in chloride-regulatory mechanisms and $\mathrm{GABA}(\mathrm{A})$ receptor-mediated inhibition in rat substantia nigra. $J$. Neurosci. 23, 8237-8246.

Gulinello, M., Gong, Q. H., Li, X., and Smith, S. S. (2001). Short-term exposure to a neuroactive steroid increases alpha4 GABA(A) receptor subunit levels in association with increased anxiety in the female rat. Brain Res. 910, 55-66.

Gyermek, L., Iriarte, J., and Crabbe, P. (1968). Steroids. CCCX. Structureactivity relationship of some steroidal hypnotic agents. J. Med. Chem. 11, 117-125.

Gyermek, L., and Soyka, L. F. (1975). Steroid anesthetics. Anesthesiology 42, 331-344.

Haage, D., Backstrom, T., and Johansson, S. (2005). Interaction between allopregnanolone and pregnenolone sulfate in modulating GABA-mediated synaptic currents in neurons from the rat medial preoptic nucleus. Brain Res. 1033, 58-67.

Haage, D., Druzin, M., and Johansson, S. (2002). Allopregnanolone modulates spontaneous GABA release via presynaptic $\mathrm{Cl}$ - permeability in rat preoptic nerve terminals. Brain Res. 958, 405-413.

Haage, D., and Johansson, S. (1999). Neurosteroid modulation of synaptic and GABA-evoked currents in neurons from the rat medial preoptic nucleus. J. Neurophysiol. 82, 143-151. 
Haas, K. F., and Macdonald, R. L. (1999). GABAA receptor subunit gamma2 and delta subtypes confer unique kinetic properties on recombinant GABAA receptor currents in mouse fibroblasts. J. Physiol. (Lond.) 514(Pt 1), $27-45$

Hadingham, K. L., Wingrove, P. B., Wafford, K. A., Bain, C., Kemp, J. A., Palmer, K. J., Wilson, A. W., Wilcox, A. S., Sikela, J. M., and Ragan, C. I. (1993). Role of the beta subunit in determining the pharmacology of human gamma-aminobutyric acid type A receptors. Mol. Pharmacol. 44, 1211-1218.

Halbreich, U. (2003). The etiology, biology, and evolving pathology of premenstrual syndromes. Psychoneuroendocrinology 28(Suppl. 3), 55-99.

Hamann, M., Rossi, D. J., and Attwell, D. (2002). Tonic and spillover inhibition of granule cells control information flow through cerebellar cortex. Neuron 33, 625-633.

Hamilton, N. M. (2002). Interaction of steroids with the GABA(A) receptor. Curr. Top. Med. Chem. 2, 887-902.

Harney, S. C., Frenguelli, B. G., and Lambert, J. J. (2003). Phosphorylation influences neurosteroid modulation of synaptic GABAA receptors in rat CAl and dentate gyrus neurones. Neuropharmacology 45, 873-883.

Harris, R. A., Proctor, W. R., McQuilkin, S. J., Klein, R. L., Mascia, M. P., Whatley, V., Whiting, P. J., and Dunwiddie, T. V. (1995). Ethanol increases GABAA responses in cells stably transfected with receptor subunits. Alcohol. Clin. Exp. Res. 19, 226-232.

Havlikova, H., Hill, M., Kancheva, L., Vrbikova, J., Pouzar, V., Cerny, I., Kancheva, R., and Starka, L. (2006). Serum profiles of free and conjugated neuroactive pregnanolone isomers in nonpregnant women of fertile age. J. Clin. Endocrinol. Metab. 91, 3092-3099.

Hawkinson, J. E., Kimbrough, C. L., Belelli, D., Lambert, J. J., Purdy, R. H., and Lan, N. C. (1994a). Correlation of neuroactive steroid modulation of [35S]tbutylbicyclophosphorothionate and $[3 \mathrm{H}]$ flunitrazepam binding and gamma-aminobutyric acidA receptor function. Mol. Pharmacol. 46, 977-985.

Hawkinson, J. E., Kimbrough, C. L., McCauley, L. D., Bolger, M. B., Lan, N. C., and Gee, K. W. (1994b). The neuroactive steroid 3 alphahydroxy- 5 beta-pregnan-20-one is a two-component modulator of ligand binding to the GABAA receptor. Eur. J. Pharmacol. 269, 157-163.

Henderson, V. W., Paganini-Hill, A., Emanuel, C. K., Dunn, M. E., and Buckwalter, J. G. (1994). Estrogen replacement therapy in older women. Comparisons between Alzheimer's disease cases and nondemented control subjects. Arch. Neurol. 51, 896-900.

Hill, M., Bicikova, M., Parizek, A., Havlikova, H., Klak, J., Fajt, T., Meloun, M., Cibula, D., Cegan, A., Sulcova, J., Hampl, R., and Starka, L. (2001). Neuroactive steroids, their precursors and polar conjugates during parturition and postpartum in maternal blood: 2. Time profiles of pregnanolone isomers. J. Steroid Biochem. Mol. Biol. 78, 51-57.

Hillen, T., Lun, A., Reischies, F. M., Borchelt, M., Steinhagen-Thiessen, E., and Schaub, R. T. (2000). DHEA$S$ plasma levels and incidence of Alzheimer's disease. Biol. Psychiatry 47, 161-163.

Hogenkamp, D. J., Tahir, S. H., Hawkinson, J. E., Upasani, R. B., Alauddin, M., Kimbrough, C. L., AcostaBurruel, M., Whittemore, E. R., Woodward, R. M., Lan, N. C. Gee, K. W., and Bolger, M. B. (1997). Synthesis and in vitro activity of 3 beta-substituted-3 alphahydroxypregnan-20-ones: allosteric modulators of the GABAA receptor. J. Med. Chem. 40, 61-72.

Hosie, A. M., Clarke, L., da Silva, H., and Smart, T. G. (2009). Conserved site for neurosteroid modulation of GABA A receptors. Neuropharmacology 56, 149-154.

Hosie, A. M., Dunne, E. L., Harvey, R. J., and Smart, T. G. (2003). Zincmediated inhibition of GABA(A) receptors: discrete binding sites underlie subtype specificity. Nat. Neurosci. 6, 362-369.

Hosie, A. M., Wilkins, M. E., da Silva, H. M., and Smart, T. G. (2006). Endogenous neurosteroids regulate GABAA receptors through two discrete transmembrane sites. Nature 444, 486-489.

Hosie, A. M., Wilkins, M. E., and Smart, T. G. (2007). Neurosteroid binding sites on GABA(A) receptors. Pharmacol. Ther. 116, 7-19.

Hutcheon, B., Morley, P., and Poulter, M. O. (2000). Developmental change in GABAA receptor desensitization kinetics and its role in synapse function in rat cortical neurons. J. Physiol. (Lond.) 522( $\mathrm{Pt} \mathrm{1),}$ 3-17.

Imamura, M., and Prasad, C. (1998). Modulation of GABA-gated chloride ion influx in the brain by dehydroepiandrosterone and its metabolites. Biochem. Biophys. Res. Commun. 243, 771-775.

Jia, F., Pignataro, L., Schofield, C. M., Yue, M., Harrison, N. L., and Goldstein, P. A. (2005). An extrasynaptic
GABAA receptor mediates tonic inhibition in thalamic VB neurons. J. Neurophysiol. 94, 4491-4501.

Johansson, I. M., Birzniece, V., Lindblad, C., Olsson, T., and Backstrom, T. (2002). Allopregnanolone inhibits learning in the Morris water maze. Brain Res. 934, 125-131.

Jones, M. V., and Westbrook, G. L. (1995). Desensitized states prolong GABAA channel responses to brief agonist pulses. Neuron 15, 181-191.

Kahle, K. T., Staley, K. J., Nahed, B. V., Gamba, G., Hebert, S. C., Lifton, R. P., and Mount, D. B. (2008). Roles of the cation-chloride cotransporters in neurological disease. Nat. Clin. Pract. Neurol. 4, 490-503.

Kancheva, L., Havlikova, H., Hill, M. Vrbikova, J., and Starka, L. (2007). "Neuroactive steroids in adult men," in 4th International Meeting Steroids and Nervous system, Torino, 152.

Kendell, R. E., McGuire, R. J., Connor,Y., and Cox, J. L. (1981). Mood changes in the first three weeks after childbirth. J. Affect. Disord. 3, 317-326.

Kennedy, R. T., Thompson, J. E., and Vickroy, T. W. (2002). In vivo monitoring of amino acids by direct sampling of brain extracellular fluid at ultralow flow rates and capillary electrophoresis. J. Neurosci. Methods 114, 39-49.

Kerr, D. I., and Ong, J. (1992). GABA agonists and antagonists. Med. Res. Rev. 12, 593-636.

Khirug, S., Yamada, J., Afzalov, R. Voipio, J., Khiroug, L., and Kaila, K. (2008). GABAergic depolarization of the axon initial segment in cortical principal neurons is caused by the $\mathrm{Na}-\mathrm{K}-2 \mathrm{Cl}$ cotransporter NKCC1. J. Neurosci. 28, 4635-4639.

Kittler, J. T., Wang, J., Connolly, C. N. Vicini, S., Smart, T. G., and Moss, S. J. (2000). Analysis of GABAA receptor assembly in mammalian cell lines and hippocampal neurons using gamma 2 subunit green fluorescent protein chimeras. Mol. Cell. Neurosci. 16, 440-452.

Klangkalya, B., and Chan, A. (1988). Structure-activity relationships of steroid hormones on muscarinic receptor binding. J. Steroid Biochem. $29,111-118$.

Klausberger, T., Ehya, N., Fuchs, K., Fuchs, T., Ebert, V., Sarto, I., and Sieghart, W. (2001). Detection and binding properties of $\mathrm{GABA}(\mathrm{A})$ receptor assembly intermediates. $J$. Biol. Chem. 276, 16024-16032.

Knight, A. R., Stephenson, F. A., Tallman, J. F., and Ramabahdran, T. V. (2000). Monospecific antibodies as probes for the stoichiometry of recombinant $\mathrm{GABA}(\mathrm{A})$ receptors. Recept. Channels 7, 213-226.
Koksma, J. J., van Kesteren, R. E., Rosahl, T. W., Zwart, R., Smit, A. B., Luddens, H., and Brussaard, A. B. (2003). Oxytocin regulates neurosteroid modulation of $\mathrm{GABA}(\mathrm{A})$ receptors in supraoptic nucleus around parturition. J. Neurosci. 23, 788-797.

Korpi, E. R., Debus, F., Linden, A. M., Malecot, C., Leppa, E., Vekovischeva, O., Rabe, H., Bohme, I., Aller, M. I., Wisden, W., and Luddens, H. (2007). Does ethanol act preferentially via selected brain GABAA receptor subtypes? The current evidence is ambiguous. Alcohol 41, 163-176.

Kurthen, M., Linke, D. B., Reuter, B. M., Hufnagel, A., and Elger, C. E. (1991). Severe negative emotional reactions in intracarotid sodium amytal procedures: further evidence for hemispheric asymmetries? Cortex 27, 333-337.

Lambert, J. J., Belelli, D., Hill-Venning, C., Callachan, H., and Peters, J. A. (1996). Neurosteroid modulation of native and recombinant GABAA receptors. Cell. Mol. Neurobiol. 16, 155-174.

Lambert, J. J., Belelli, D., Hill-Venning, C., and Peters, J. A. (1995). Neurosteroids and GABAA receptor function. Trends Pharmacol. Sci. 16, 295-303.

Lambert, J. J., Harney, S. C., Belelli, D., and Peters, J. A. (2001a). Neurosteroid modulation of recombinant and synaptic GABAA receptors. Int. Rev. Neurobiol. 46, 177-205.

Lambert, J. J., Belelli, D., Harney, S. C. Peters, J. A., and Frenguelli, B. G. (2001b). Modulation of native and recombinant $\mathrm{GABA}(\mathrm{A})$ receptors by endogenous and synthetic neuroactive steroids. Brain Res. Brain Res. Rev. 37, 68-80.

Landgren, S., Aasly, J., Backstrom, T., Dubrovsky, B., and Danielsson, E. (1987). The effect of progesterone and its metabolites on the interic tal epileptiform discharge in the cat's cerebral cortex. Acta Physiol. Scand. $131,33-42$.

Landgren, S., Wang, M. D., Backstrom, T., and Johansson, S. (1998). Interaction between 3 alpha-hydroxy5 alpha-pregnan-20-one and carbachol in the control of neuronal excitability in hippocampal slices of female rats in defined phases of the oestrus. Acta Physiol. Scand. 162, 77-88.

Lanthier, A., and Patwardhan, V. V. (1986). Sex steroids and 5-en-3 betahydroxysteroids in specific regions of the human brain and cranial nerves. J. Steroid Biochem. 25, 445-449. 
Laubach, G. D., P'An, S. Y., and Rudel, H. W. (1955). Steroid anesthetic agent. Science 122, 78.

Lavoie, A. M., Tingey, J. J., Harrison, N. L., Pritchett, D. B., and Twyman, R. E. (1997). Activation and deactivation rates of recombinant $\mathrm{GABA}(\mathrm{A})$ receptor channels are dependent on alpha-subunit isoform. Biophys. J. 73, 2518-2526.

Lee, G. P., Loring, D. W., Meador, K. J., Flanigin, H. F., and Brooks, B. S. (1988). Severe behavioral complications following intracarotid sodium amobarbital injection: implications for hemispheric asymmetry of emotion. Neurology 38, 1233-1236.

Lerma, J., Herranz, A. S., Herreras, O., Abraira, V., and Martin del Rio, R. (1986). In vivo determination of extracellular concentration of amino acids in the rat hippocampus. A method based on brain dialysis and computerized analysis. Brain Res. $384,145-155$.

Leroy, C., Poisbeau, P., Keller, A. F., and Nehlig, A. (2004). Pharmacological plasticity of GABA(A) receptors at dentate gyrus synapses in a rat model of temporal lobe epilepsy. J. Physiol. (Lond.) 557, 473-487.

Li, G. D., Chiara, D. C., Cohen, J. B., and Olsen, R. W. (2009). Neurosteroids allosterically modulate binding of the anesthetic etomidate to gammaaminobutyric acid type A receptors. J. Biol. Chem. 284, 11771-11775.

Li, P., Khatri, A., Bracamontes, J., Weiss, D. S., Steinbach, J. H., and Akk, G. (2010). Site-specific fluorescence reveals distinct structural changes induced in the human rho 1 GABA receptor by inhibitory neurosteroids. Mol. Pharmacol. 77, 539-546.

Li, W., Jin, X., Covey, D. F., and Steinbach, J. H. (2007). Neuroactive steroids and human recombinant rhol GABAC receptors. J. Pharmacol. Exp. Ther. 323, 236-247.

Liang, J., Cagetti, E., Olsen, R. W., and Spigelman, I. (2004). Altered pharmacology of synaptic and extrasynaptic GABAA receptors on CA1 hippocampal neurons is consistent with subunit changes in a model of alcohol withdrawal and dependence. J. Pharmacol. Exp. Ther. 310, 1234-1245.

Lofgren, M., Johansson, I. M., Meyerson, B., Lundgren, P., and Backstrom, T. (2006). Progesterone withdrawal effects in the open field test can be predicted by elevated plus maze performance. Horm. Behav. 50, 208-215.

Luisi, S., Petraglia, F., Benedetto, C., Nappi, R. E., Bernardi, F., Fadalti, M., Reis, F. M., Luisi, M., and
Genazzani, A. R. (2000). Serum allopregnanolone levels in pregnant women: changes during pregnancy, at delivery, and in hypertensive patients. J. Clin. Endocrinol. Metab. 85, 2429-2433.

Lundgren, P., Stromberg, J., Backstrom, T., and Wang, M. (2003). Allopregnanolone-stimulated GABA-mediated chloride ion flux is inhibited by 3betahydroxy-5alpha-pregnan-20-one (isoallopregnanolone). Brain Res. 982, 45-53.

Lupien, S. J., Fiocco, A., Wan, N., Maheu, F., Lord, C., Schramek, T., and Tu, M. T. (2005). Stress hormones and human memory function across the lifespan. Psychoneuroendocrinology 30, 225-242.

Macdonald, R. L., and Olsen, R. W. (1994). GABAA receptor channels. Annu. Rev. Neurosci. 17, 569-602.

Maione, S., Berrino, L., Vitagliano, S. Leyva, J., and Rossi, F. (1992). Pregnenolone sulfate increases the convulsant potency of N-methyl-Daspartate in mice. Eur. J. Pharmacol. $219,477-479$.

Maitra, R., and Reynolds, J. N. (1998). Modulation of GABA(A) receptor function by neuroactive steroids: evidence for heterogeneity of steroid sensitivity of recombinant $\mathrm{GABA}(\mathrm{A})$ receptor isoforms. Can. J. Physiol. Pharmacol. 76, 909-920.

Maitra, R., and Reynolds, J. N. (1999). Subunit dependent modulation of GABAA receptor function by neuroactive steroids. Brain Res. 819, 75-82.

Majewska, M. D. (1992). Neurosteroids: endogenous bimodal modulators of the GABAA receptor. Mechanism of action and physiological significance. Prog. Neurobiol. 38, 379-395.

Majewska, M. D., Demirgoren, S., Spivak, C. E., and London, E. D. (1990). The neurosteroid dehydroepiandrosterone sulfate is an allosteric antagonist of the GABAA receptor. Brain Res. 526, 143-146.

Majewska, M. D., Harrison, N. L., Schwartz, R. D., Barker, J. L., and Paul, S. M. (1986). Steroid hormone metabolites are barbituratelike modulators of the GABA receptor. Science 232, 1004-1007.

Majewska, M. D., Mienville, J. M., and Vicini, S. (1988). Neurosteroid pregnenolone sulfate antagonizes electrophysiological responses to GABA in neurons. Neurosci. Lett. 90, 279-284.

Majewska, M. D., and Schwartz, R. D. (1987). Pregnenolone-sulfate: an endogenous antagonist of the gamma-aminobutyric acid receptor complex in brain? Brain Res. 404, 355-360.

Martina, M., Royer, S., and Pare, D. (2001). Cell-type-specific GABA responses and chloride homeostasis in the cortex and amygdala. $J$. Neurophysiol. 86, 2887-2895.

Masia, S. L., Perrine, K., Westbrook, L., Alper, K., and Devinsky, O. (2000). Emotional outbursts and post-traumatic stress disorder during intracarotid amobarbital procedure. Neurology 54 1691-1693.

Maubach, K. (2003). GABA(A) receptor subtype selective cognition enhancers. Curr. Drug Targets CNS Neurol. Disord. 2, 233-239.

Mayo, W., Dellu, F., Robel, P., Cherkaoui, J., Le Moal, M., Baulieu, E. E., and Simon, H. (1993). Infusion of neurosteroids into the nucleus basalis magnocellularis affects cognitive processes in the rat. Brain Res. 607, 324-328.

McEwen, B. S. (1991). Non-genomic and genomic effects of steroids on neural activity. Trends Pharmacol. Sci. 12, 141-147.

McKernan, R. M., and Whiting, P. J. (1996). Which GABAA-receptor subtypes really occur in the brain? Trends Neurosci. 19, 139-143.

Mehta, A. K., and Ticku, M. K. (1999). An update on GABAA receptors. Brain Res. Brain Res. Rev. 29, 196-217.

Melchior, C. L., and Ritzmann, R. F. (1996). Neurosteroids block the memory-impairing effects of ethanol in mice. Pharmacol. Biochem. Behav. 53, 51-56.

Mellon, S. H. (2007). Neurosteroid regulation of central nervous system development. Pharmacol. Ther. 116, 107-124.

Mellon, S. H., Griffin, L. D., and Compagnone, N. A. (2001). Biosynthesis and action of neurosteroids. Brain Res. Brain Res. Rev. 37, 3-12.

Mennerick, S., He, Y., Jiang, X., Manion, B. D., Wang, M., Shute, A., Benz, A. Evers, A. S., Covey, D. F., and Zorumski, C. F. (2004). Selective antagonism of 5alpha-reduced neurosteroid effects at $\mathrm{GABA}(\mathrm{A})$ receptors. Mol. Pharmacol. 65, 1191-1197.

Mennerick, S., Zeng, C. M., Benz, A., Shen, W., Izumi, Y., Evers, A. S., Covey, D. F., and Zorumski, C. F. (2001). Effects on gammaaminobutyric acid (GABA)(A) receptors of a neuroactive steroid that negatively modulates glutamate neurotransmission and augments GABA neurotransmission. Mol. Pharmacol. 60 732-741.

Mensah-Nyagan, A. G., Do-Rego, J. L., Beaujean, D., Luu-The, V., Pelletier,
G., and Vaudry, H. (1999). Neurosteroids: expression of steroidogenic enzymes and regulation of steroid biosynthesis in the central nervous system. Pharmacol. Rev. 51, 63-81.

Meyerson, B. J. (1967). Relationship between the anesthetic and gestagenic action and estrous behavior-inducing activity of different progestins. Endocrinology 81, 369-374.

Miczek, K. A., Fish, E. W., and De Bold, J. F. (2003). Neurosteroids, GABAA receptors, and escalated aggressive behavior. Horm. Behav. 44, 242-257.

Mienville, J. M., and Vicini, S. (1989). Pregnenolone sulfate antagonizes GABAA receptor-mediated currents via a reduction of channel opening frequency. Brain Res. 489, 190-194.

Mihalek, R. M., Banerjee, P. K., Korpi, E. R., Quinlan, J. J., Firestone, L. L., Mi, Z. P., Lagenaur, C., Tretter, V., Sieghart, W., Anagnostaras, S. G., Sage, J. R., Fanselow, M. S., Guidotti, A., Spigelman, I., Li, Z., DeLorey, T. M., Olsen, R. W., and Homanics, G. E. (1999). Attenuated sensitivity to neuroactive steroids in gammaaminobutyrate type A receptor delta subunit knockout mice. Proc. Natl. Acad. Sci. U.S.A. 96, 12905-12910.

Miklos, I. H., and Kovacs, K. J. (2002). GABAergic innervation of corticotropin-releasing hormone (CRH)-secreting parvocellular neurons and its plasticity as demonstrated by quantitative immunoelectron microscopy. Neuroscience 113, 581-592.

Miller, L. G., Greenblatt, D. J., Barnhill, J. G., and Shader, R. I. (1988). Chronic benzodiazepine administration. I. Tolerance is associated with benzodiazepine receptor downregulation and decreased gammaaminobutyric acidA receptor function. J. Pharmacol. Exp. Ther. 246, 170-176.

Mitchell, E. A., Herd, M. B., Gunn B. G., Lambert, J. J., and Belelli, D. (2008). Neurosteroid modulation of GABAA receptors: molecular determinants and significance in health and disease. Neurochem. Int. 52, 588-595.

Mitchell, S. J., and Silver, R. A. (2003). Shunting inhibition modulates neuronal gain during synaptic excitation. Neuron 38, 433-445.

Mody, I. (2001). Distinguishing between $\mathrm{GABA}(\mathrm{A})$ receptors responsible for tonic and phasic conductances. Neurochem. Res. 26, 907-913.

Mody, I. (2008). Extrasynaptic GABAA receptors in the crosshairs of hormones and ethanol. Neurochem. Int. $52,60-64$. 
Mody, I., De Koninck, Y., Otis, T. S., and Soltesz, I. (1994). Bridging the cleft at GABA synapses in the brain. Trends Neurosci. 17, 517-525.

Moenter, S. M., and DeFazio, R. A. (2005). Endogenous gammaaminobutyric acid can excite gonadotropin-releasing hormone neurons. Endocrinology 146, 5374-5379.

Mohammed, A. K., Wahlstrom, G., Tiger, G., Bjorklund, P. E., Stenstrom, A., Magnusson, O., Archer, T., Fowler, C. J., and Nordberg, A. (1987). Impaired performance of rats in the Morris swim-maize test late in abstinence following longterm sodium barbital treatment. Drug Alcohol Depend. 20, 203-212.

Mohler, H., Crestani, F., and Rudolph, U. (2001). GABA(A)-receptor subtypes: a new pharmacology. Curr. Opin. Pharmacol. 1, 22-25.

Mohler, H., Fritschy, J. M., Crestani, F., Hensch, T., and Rudolph, U. (2004). Specific GABA(A) circuits in brain development and therapy. Biochem. Pharmacol. 68, 1685-1690.

Mohler, H., Fritschy, J. M., and Rudolph, U. (2002). A new benzodiazepine pharmacology. J. Pharmacol. Exp. Ther. 300, 2-8

Morris, K. D., Moorefield, C. N., and Amin, J. (1999). Differential modulation of the gamma-aminobutyric acid type $\mathrm{C}$ receptor by neuroactive steroids. Mol. Pharmacol. 56, 752-759.

Mozrzymas, J. W., Zarnowska, E. D., Pytel, M., and Mercik, K. (2003). Modulation of $\operatorname{GABA}(\mathrm{A})$ receptors by hydrogen ions reveals synaptic GABA transient and a crucial role of the desensitization process. $\mathrm{J}$. Neurosci. 23, 7981-7992.

Nakamura, N. H., Rosell, D. R., Akama, K. T., and McEwen, B. S. (2004). Estrogen and ovariectomy regulate mRNA and protein of glutamic acid decarboxylases and cation-chloride cotransporters in the adult rat hippocampus. Neuroendocrinology 80, 308-323.

Nasman, B., Olsson, T., Backstrom, T., Eriksson, S., Grankvist, K., Viitanen, M., and Bucht, G. (1991). Serum dehydroepiandrosterone sulfate in Alzheimer's disease and in multiinfarct dementia. Biol. Psychiatry 30, 684-690.

Nasman, B., Olsson, T., Fagerlund, M., Eriksson, S., Viitanen, M., and Carlstrom, K. (1996). Blunted adrenocorticotropin and increased adrenal steroid response to human corticotropin-releasing hormone in Alzheimer's disease. Biol. Psychiatry 39, 311-318.

Nasman, B., Olsson, T., Viitanen, M., and Carlstrom, K. (1995). A subtle disturbance in the feedback regulation of the hypothalamic-pituitaryadrenal axis in the early phase of Alzheimer's disease. Psychoneuroendocrinology 20, 211-220.

Nayeem, N., Green, T. P., Martin, I. L., and Barnard, E. A. (1994). Quaternary structure of the native GABAA receptor determined by electron microscopic image analysis. J. Neurochem. 62, 815-818.

Nguyen, Q., Sapp, D. W., Van Ness, P. C., and Olsen, R. W. (1995). Modulation of GABAA receptor binding in human brain by neuroactive steroids: species and brain regional differences. Synapse 19, 77-87.

Nusser, Z., Cull-Candy, S., and Farrant, M. (1997). Differences in synaptic $\mathrm{GABA}(\mathrm{A})$ receptor number underlie variation in GABA mini amplitude. Neuron 19, 697-709.

Nusser, Z., and Mody, I. (2002). Selective modulation of tonic and phasic inhibitions in dentate gyrus granule cells. J. Neurophysiol. 87, 2624-2628.

Nusser, Z., Sieghart, W., and Somogyi, P. (1998). Segregation of different GABAA receptors to synaptic and extrasynaptic membranes of cerebellar granule cells. J. Neurosci. 18, 1693-1703.

Nyberg, S., Wahlstrom, G., Backstrom, T., and Sundstrom Poromaa, I. (2004). Altered sensitivity to alcohol in the late luteal phase among patients with premenstrual dysphoric disorder. Psychoneuroendocrinology 29, 767-777.

Ottander, U., Poromaa, I. S., Bjurulf, E., Skytt, A., Backstrom, T., and Olofsson, J. I. (2005). Allopregnanolone and pregnanolone are produced by the human corpus luteum. Mol. Cell. Endocrinol. 239, 37-44.

Park-Chung, M., Malayev, A., Purdy, R. H., Gibbs, T. T., and Farb, D. H. (1999). Sulfated and unsulfated steroids modulate gammaaminobutyric acidA receptor function through distinct sites. Brain Res. 830, 72-87.

Parry, B. L. (2001). The role of central serotonergic dysfunction in the aetiology of premenstrual dysphoric disorder: therapeutic implications. CNS Drugs 15, 277-285.

Paul, S. M., and Purdy, R. H. (1992). Neuroactive steroids. FASEB J. 6, 2311-2322.

Pirker, S., Schwarzer, C., Wieselthaler, A., Sieghart, W., and Sperk, G. (2000). GABA(A) receptors: immunocytochemical distribution of 13 subunits in the adult rat brain. Neuroscience 101, 815-850.

Poisbeau, P., Feltz, P., and Schlichter, R. (1997). Modulation of GABAA receptor-mediated IPSCs by neuroactive steroids in a rat hypothalamo-hypophyseal coculture model. J. Physiol. (Lond.) 500(Pt 2), 475-485.

Porcello, D. M., Huntsman, M. M., Mihalek, R. M., Homanics, G. E. and Huguenard, J. R. (2003). Intact synaptic GABAergic inhibition and altered neurosteroid modulation of thalamic relay neurons in mice lacking delta subunit. J. Neurophysiol. 89 , 1378-1386.

Prescott, S. A., Sejnowski, T. J., and De Koninck, Y. (2006). Reduction of anion reversal potential subverts the inhibitory control of firing rate in spinal lamina I neurons: towards a biophysical basis for neuropathic pain. Mol. Pain 2, 32.

Price, T. J., Cervero, F., and de Koninck, Y. (2005). Role of cation-chloridecotransporters (CCC) in pain and hyperalgesia. Curr. Top. Med. Chem. 5, 547-555.

Price, T. J., Cervero, F., Gold, M. S., Hammond, D. L., and Prescott, S. A. (2009). Chloride regulation in the pain pathway. Brain Res. Rev. 60, 149-170.

Puia, G., Ducic, I., Vicini, S., and Costa, E. (1993). Does neurosteroid modulatory efficacy depend on GABAA receptor subunit composition? Recept. Channels 1, 135-142.

Puia, G., Santi, M. R., Vicini, S., Pritchett, D. B., Purdy, R. H., Paul, S. M., Seeburg, P. H., and Costa, E. (1990). Neurosteroids act on recombinant human GABAA receptors. Neuron 4 759-765.

Purdy, R. H., Moore, P. H. Jr., Morrow, A. L., and Paul, S. M. (1992) Neurosteroids and GABAA receptor function. Adv. Biochem. Psychopharmacol. 47, 87-92.

Purdy, R. H., Morrow, A. L., Blinn, J. R., and Paul, S. M. (1990). Synthesis, metabolism, and pharmacological activity of 3 alpha-hydroxy steroids which potentiate GABA-receptormediated chloride ion uptake in rat cerebral cortical synaptoneurosomes. J. Med. Chem. 33, 1572-1581.

Purdy, R. H., Morrow, A. L., Moore, P. H. Jr., and Paul, S. M. (1991). Stressinduced elevations of gammaaminobutyric acid type A receptoractive steroids in the rat brain. Proc. Natl. Acad. Sci. U.S.A. 88, 4553-4557.

Purvez, D., Augustine, G. J., Fitzpatrick, D., Hall, W. C., LaMantia, A. S., McNamara, J. O., and Williams, S. M. (2004). Neuroscience, 3rd Edn. Sunderland: Sinauer Associates Inc., 143.

Ragagnin, G., Rahman, M., Zingmark, E., Stromberg, J., Lundgren, P., Wang, M., and Backstrom, T. (2007). "Structure actvity relationship of
GABAA-steroids antagonists," in 4th International Meeting - Steroids and Nervous system, Torino, 197.

Rahman, M., Lindblad, C., Johansson, I. M., Backstrom, T., and Wang, M. D. (2006). Neurosteroid modulation of recombinant rat alpha(5)beta(2)gamma(2L) and alpha(1)beta(2)gamma(2L) GABA(A) receptors in Xenopus oocyte. Eur. J. Pharmacol. 547, 37-44.

Rasmuson, S., Andrew, R., Nasman, B., Seckl, J. R., Walker, B. R., and Olsson, T. (2001). Increased glucocorticoid production and altered cortisol metabolism in women with mild to moderate Alzheimer's disease. Biol. Psychiatry 49, 547-552.

Reddy, D. S. (2003). Is there a physiological role for the neurosteroid THDOC in stress-sensitive conditions? Trends Pharmacol. Sci. 24, 103-106.

Reddy, D. S., and Kulkarni, S. K. (2000). Development of neurosteroid-based novel psychotropic drugs. Prog. Med. Chem. 37, 135-175.

Reddy, D. S., and Rogawski, M. A. (2002). Stress-induced deoxycorticosterone-derived neurosteroids modulate GABA(A) receptor function and seizure susceptibility. J. Neurosci. 22, 3795-3805.

Rick, C. E., Ye, Q., Finn, S. E., and Harrison, N. L. (1998). Neurosteroids act on the GABA(A) receptor at sites on the $\mathrm{N}$-terminal side of the middle of TM2. Neuroreport 9 , 379-383.

Riedel, G., Platt, B., and Micheau, J. (2003). Glutamate receptor function in learning and memory. Behav. Brain Res. 140, $1-47$.

Rodgers, R. J., and Johnson, N. J. (1998). Behaviorally selective effects of neuroactive steroids on plus-maze anxiety in mice. Pharmacol. Biochem. Behav. 59, 221-232.

Rudolph, U., Crestani, F., Benke, D., Brunig, I., Benson, J. A., Fritschy, J. M., Martin, J. R., Bluethmann, H., and Mohler, H. (1999). Benzodiazepine actions mediated by specific gamma-aminobutyric acid(A) receptor subtypes. Nature 401, 796-800.

Rudolph, U., Crestani, F., and Mohler, H. (2001). GABA(A) receptor subtypes: dissecting their pharmacological functions. Trends Pharmacol. Sci. 22, 188-194.

Rupprecht, R. (2003). Neuroactive steroids: mechanisms of action and neuropsychopharmacological properties. Psychoneuroendocrinology 28, 139-168. 
Rupprecht, R., di Michele, F., Hermann, B., Strohle, A., Lancel, M., Romeo, E., and Holsboer, F. (2001). Neuroactive steroids: molecular mechanisms of action and implications for neuropsychopharmacology. Brain Res. Brain Res. Rev. 37, 59-67.

Rupprecht, R., Reul, J. M., Trapp, T., van Steensel, B., Wetzel, C., Damm, K., Zieglgansberger, W., and Holsboer, F. (1993). Progesterone receptormediated effects of neuroactive steroids. Neuron 11, 523-530.

Sandstrom, A., Rhodin, I. N., Lundberg, M., Olsson, T., and Nyberg, L. (2005). Impaired cognitive performance in patients with chronic burnout syndrome. Biol. Psychol. 69, 271-279.

Sanna, E., Murgia, A., Casula, A., and Biggio, G. (1997). Differential subunit dependence of the actions of the general anesthetics alphaxalone and etomidate at gamma-aminobutyric acid type A receptors expressed in Xenopus laevis oocytes. Mol. Pharmacol. 51, 484-490.

Saunders, P. A., Copeland, J. R., Dewey, M. E., Davidson, I. A., McWilliam, C., Sharma, V., and Sullivan, C. (1991). Heavy drinking as a risk factor for depression and dementia in elderly men. Findings from the Liverpool longitudinal community study. Br. J. Psychiatry 159, 213-216.

Saxena, N. C., and Macdonald, R. L. (1994). Assembly of GABAA receptor subunits: role of the delta subunit. J. Neurosci. 14, 7077-7086.

Saxena, N. C., and Macdonald, R. L. (1996). Properties of putative cerebellar gamma-aminobutyric acid A receptor isoforms. Mol. Pharmacol. 49, 567-579.

Schofield, P. R., Darlison, M. G., Fujita, N., Burt, D. R., Stephenson, F. A., Rodriguez, H., Rhee, L. M., Ramachandran, J., Reale, V., Glencorse, T. A., Seeburg, P. H., and Barnard, E. A. (1987). Sequence and functional expression of the GABA A receptor shows a ligand-gated receptor super-family. Nature 328, 221-227.

Schumacher, M., Akwa, Y., Guennoun, R., Robert, F., Labombarda, F., Desarnaud, F., Robel, P., De Nicola, A. F., and Baulieu, E. E. (2000). Steroid synthesis and metabolism in the nervous system: trophic and protective effects. J. Neurocytol. 29, 307-326.

Sear, J. W. (1997). ORG 21465, a new water-soluble steroid hypnotic: more of the same or something different? Br. J. Anaesth. 79, 417-419.

Semyanov, A., Walker, M. C., and Kullmann, D. M. (2003). GABA uptake regulates cortical excitability via cell type-specific tonic inhibition. Nat. Neurosci. 6, 484-490.

Semyanov, A., Walker, M. C., Kullmann, D. M., and Silver, R. A. (2004). Tonically active GABA A receptors: modulating gain and maintaining the tone. Trends Neurosci. 27, 262-269.

Serra, M., Pisu, M. G., Floris, I., Cara, V., Purdy, R. H., and Biggio, G. (2003). Social isolation-induced increase in the sensitivity of rats to the steroidogenic effect of ethanol. J. Neurochem. 85, 257-263.

Serra, M., Pisu, M. G., Littera, M., Papi, G., Sanna, E., Tuveri, F., Usala, L., Purdy, R. H., and Biggio, G. (2000). Social isolation-induced decreases in both the abundance of neuroactive steroids and GABA(A) receptor function in rat brain. J. Neurochem. 75, 732-740.

Shen, H., Gong, Q. H., Aoki, C., Yuan, M., Ruderman, Y., Dattilo, M., Williams, K., and Smith, S. S. (2007). Reversal of neurosteroid effects at alpha4beta2delta GABAA receptors triggers anxiety at puberty. Nat. Neurosci. 10, 469-477.

Shen, W., Mennerick, S., Covey, D. F., and Zorumski, C. F. (2000). Pregnenolone sulfate modulates inhibitory synaptic transmission by enhancing $\mathrm{GABA}(\mathrm{A})$ receptor desensitization. J. Neurosci. 20, 3571-3579.

Shen, W., Mennerick, S., Zorumski, E. C., Covey, D. F., and Zorumski, C. F. (1999). Pregnenolone sulfate and dehydroepiandrosterone sulfate inhibit GABA-gated chloride currents in Xenopus oocytes expressing picrotoxin-insensitive GABA(A) receptors. Neuropharmacology 38, 267-271.

Shu, H. J., Eisenman, L. N., Jinadasa, D., Covey, D. F., Zorumski, C. F., and Mennerick, S. (2004). Slow actions of neuroactive steroids at GABAA receptors. J. Neurosci. 24, 6667-6675.

Shumaker, S. A., Legault, C., Kuller, L., Rapp, S. R., Thal, L., Lane, D. S., Fillit, H., Stefanick, M. L., Hendrix, S. L., Lewis, C. E., Masaki, K., and Coker, L. H. (2004). Conjugated equine estrogens and incidence of probable dementia and mild cognitive impairment in postmenopausal women: Women's Health Initiative Memory Study. JAMA 291, 2947-2958.

Shumaker, S. A., Legault, C., Rapp, S. R., Thal, L., Wallace, R. B., Ockene, J. K., Hendrix, S. L., Jones, B. N. III, Assaf, A. R., Jackson, R. D., Kotchen, J. M., Wassertheil-Smoller, S., and Wactawski-Wende, J. (2003). Estrogen plus progestin and the incidence of dementia and mild cognitive impairment in postmenopausal women: the Women's Health Initiative Memory Study: a randomized controlled trial. JAMA 289, 2651-2662.

Sieghart, W. (1992). GABAA receptors: ligand-gated $\mathrm{Cl}$ - ion channels modulated by multiple drugbinding sites. Trends Pharmacol. Sci. 13, 446-450.

Sieghart, W. (2000). Unraveling the function of GABA(A) receptor subtypes. Trends Pharmacol. Sci. 21, 411-413.

Sieghart, W., and Sperk, G. (2002). Subunit composition, distribution and function of GABA(A) receptor subtypes. Curr. Top. Med. Chem. 2, 795-816.

Sivilotti, L., and Nistri, A. (1991). GABA receptor mechanisms in the central nervous system. Prog. Neurobiol. 36 35-92.

Smart, T. G. (1992). A novel modulatory binding site for zinc on the GABAA receptor complex in cultured rat neurones. J. Physiol. (Lond.) 447, 587-625.

Smith, M. C., and Riskin, B. J. (1991). The clinical use of barbiturates in neurological disorders. Drugs 42 , 365-378.

Smith, S. S., Gong, Q. H., Hsu, F. C., Markowitz, R. S., ffrench-Mullen, J. M., and Li, X. (1998). GABA(A) receptor alpha4 subunit suppression prevents withdrawal properties of an endogenous steroid. Nature 392 926-930.

Smith, S. S., Shen, H., Gong, Q. H., and Zhou, X. (2007). Neurosteroid regulation of $\mathrm{GABA}(\mathrm{A})$ receptors: focus on the alpha4 and delta subunits. Pharmacol. Ther. 116, 58-76.

Soares, C. N., Cohen, L. S., Otto, M. W., and Harlow, B. L. (2001). Characteristics of women with premenstrual dysphoric disorder (PMDD) who did or did not report history of depression: a preliminary report from the Harvard Study of Moods and Cycles. J. Womens Health Gend. Based Med. 10, 873-878.

Solfrizzi, V., D’Introno, A., Colacicco, A. M., Capurso, C., Del Parigi, A., Baldassarre, G., Scapicchio, P., Scafato, E., Amodio, M., Capurso, A., and Panza, F. (2007). Alcohol consumption, mild cognitive impairment, and progression to dementia. $\mathrm{Neu}$ rology 68, 1790-1799.

Sousa, A., and Ticku, M. K. (1997). Interactions of the neurosteroid dehydroepiandrosterone sulfate with the $\mathrm{GABA}(\mathrm{A})$ receptor complex reveals that it may act via the picrotoxin site. J. Pharmacol. Exp. Ther. 282, 827-833.

Sperk, G., Schwarzer, C., Tsunashima, K., Fuchs, K., and Sieghart, W. (1997). GABA(A) receptor subunits in the rat hippocampus I: immunocytochemical distribution of 13 subunits. Neuroscience 80, 987-1000.

Stell, B. M., Brickley, S. G., Tang, C. Y., Farrant, M., and Mody, I. (2003). Neuroactive steroids reduce neuronal excitability by selectively enhancing tonic inhibition mediated by delta subunit-containing GABAA receptors. Proc. Natl. Acad. Sci. U.S.A. 100, 14439-14444.

Stell, B. M., and Mody, I. (2002). Receptors with different affinities mediate phasic and tonic GABA(A) conductances in hippocampal neurons. $J$. Neurosci. 22, RC223.

Stoffel-Wagner, B. (2003). Neurosteroid biosynthesis in the human brain and its clinical implications. Ann. N. Y. Acad. Sci. 1007, 64-78.

Stromberg, J., Backstrom, T., and Lundgren, P. (2005). Rapid non-genomic effect of glucocorticoid metabolites and neurosteroids on the gammaaminobutyric acid-A receptor. Eur. J. Neurosci. 21, 2083-2088.

Stromberg, J., Haage, D., Taube, M., Backstrom, T., and Lundgren, P. (2006). Neurosteroid modulation of allopregnanolone and GABA effect on the GABA-A receptor. Neuroscience 143, 73-81.

Stromstedt, M., Warner, M., Banner, C. D., MacDonald, P. C., and Gustafsson, J. A. (1993). Role of brain cytochrome $\mathrm{P} 450$ in regulation of the level of anesthetic steroids in the brain. Mol. Pharmacol. 44, 1077-1083

Sun, C., Sieghart, W., and Kapur, J. (2004). Distribution of alpha1, alpha4, gamma2, and delta subunits of GABAA receptors in hippocampal granule cells. Brain Res. 1029, 207-216.

Sunderland, T., Merril, C. R., Harrington, M. G., Lawlor, B. A., Molchan, S. E., Martinez, R., and Murphy, D. L. (1989). Reduced plasma dehydroepiandrosterone concentrations in Alzheimer's disease. Lancet 2, 570.

Sundstro, I. I., and Backstrom, T. (1999). Citalopram increases pregnanolone sensitivity in patients with premenstrual dysphoric disorder. Acta Physiol. Scand. 167 A6-A7.

Sundstrom, I., Andersson, A., Nyberg, S., Ashbrook, D., Purdy, R. H., and Backstrom, T. (1998). Patients with premenstrual syndrome have a different sensitivity to a neuroactive steroid during the menstrual cycle compared to control subjects. Neuroendocrinology 67, 126-138.

Sundstrom, I., Ashbrook, D., and Backstrom, T. (1997). Reduced benzodiazepine sensitivity in patients with premenstrual syndrome: a pilot study. Psychoneuroendocrinology 22, 25-38. 
Sundstrom Poromaa, I., Smith, S., and Gulinello, M. (2003). GABA receptors, progesterone and premenstrual dysphoric disorder. Arch. Womens Ment. Health 6, 23-41.

Sur, C., Farrar, S. J., Kerby, J., Whiting, P. J., Atack, J. R., and McKernan, R. M. (1999). Preferential coassembly of alpha4 and delta subunits of the gamma-aminobutyric acidA receptor in rat thalamus. Mol. Pharmacol. 56, 110-115.

Sveindottir, H., and Backstrom, T. (2000). Prevalence of menstrual cycle symptom cyclicity and premenstrual dysphoric disorder in a random sample of women using and not using oral contraceptives. Acta Obstet. Gynecol. Scand. 79, 405-413.

Szabadics, J., Varga, C., Molnar, G., Olah, S., Barzo, P., and Tamas, G. (2006). Excitatory effect of GABAergic axoaxonic cells in cortical microcircuits. Science 311, 233-235.

Thompson, S. A., Bonnert, T. P., Cagetti, E., Whiting, P. J., and Wafford, K. A. (2002). Overexpression of the GABA(A) receptor epsilon subunit results in insensitivity to anaesthetics. Neuropharmacology 43, 662-668.

Thompson, S. A., Whiting, P. J., and Wafford, K. A. (1996). Barbiturate interactions at the human GABAA receptor: dependence on receptor subunit combination. Br. J. Pharmacol. 117, 521-527.

Timby, E., Balgard, M., Nyberg, S., Spigset, O., Andersson, A., Porankiewicz-Asplund, J., Purdy, R. H., Zhu, D., Backstrom, T., and Poromaa, I. S. (2006). Pharmacokinetic and behavioral effects of allopregnanolone in healthy women. Psychopharmacology (Berl.) 186, 414-424.

Tossman, U., Jonsson, G., and Ungerstedt, U. (1986). Regional distribution and extracellular levels of amino acids in rat central nervous system. Acta Physiol. Scand. 127, 533-545.

Turkmen, S., Lofgren, M., Birzniece, V., Backstrom, T., and Johansson, I. M. (2006). Tolerance development to Morris water maze test impairments induced by acute allopregnanolone. Neuroscience 139, 651-659.

Turkmen, S., Lundgren, P., Birzniece, V., Zingmark, E., Backstrom, T., and Johansson, I. M. (2004). 3beta20beta-dihydroxy-5alpha-pregnane (UC1011). Antagonism of the GABA potentiation and the learning impairment induced in rats by allopregnanolone. Eur. J. Neurosci. 20, 1604-1612.

Upasani, R. B., Yang, K. C., AcostaBurruel, M., Konkoy, C. S., McLellan, J. A., Woodward, R. M., Lan, N.
C., Carter, R. B., and Hawkinson, J. E. (1997). 3 alpha-Hydroxy-3 beta(phenylethynyl)-5 beta-pregnan-20ones: synthesis and pharmacological activity of neuroactive steroids with high affinity for GABAA receptors. J. Med. Chem. 40, 73-84.

Valera, S., Ballivet, M., and Bertrand, D. (1992). Progesterone modulates a neuronal nicotinic acetylcholine receptor. Proc. Natl. Acad. Sci. U.S.A. 89, 9949-9953.

van Rijnsoever, C., Tauber, M., Choulli, M. K., Keist, R., Rudolph, U., Mohler, H., Fritschy, J. M., and Crestani, F. (2004). Requirement of alpha5GABAA receptors for the development of tolerance to the sedative action of diazepam in mice. $J$. Neurosci. 24, 6785-6790.

Vanover, K. E., Rosenzweig-Lipson, S., Hawkinson, J. E., Lan, N. C., Belluzzi, J. D., Stein, L., Barrett, J. E., Wood, P. L., and Carter, R. B. (2000). Characterization of the anxiolytic properties of a novel neuroactive steroid, Co 2-6749 (GMA-839; WAY-141839; 3alpha, 21-dihydroxy3beta-trifluoromethyl-19-nor-

5beta-pregnan-20-one), a selective modulator of gamma-aminobutyric acid(A) receptors. J. Pharmacol. Exp. Ther. 295, 337-345.

Verdoorn, T. A., Draguhn, A., Ymer, S., Seeburg, P. H., and Sakmann, B. (1990). Functional properties of recombinant rat GABAA receptors depend upon subunit composition. Neuron 4, 919-928.

Vicini, S., Losi, G., and Homanics, G. E. (2002). GABA(A) receptor delta subunit deletion prevents neurosteroid modulation of inhibitory synaptic currents in cerebellar neurons. Neuropharmacology 43, 646-650.

Vincze, G., Almos, P., Boda, K., Dome, P., Bodi, N., Szlavik, G., Magloczki, E., Pakaski, M., Janka, Z., and Kalman, J. (2007). Risk factors of cognitive decline in residential care in Hungary. Int. J. Geriatr. Psychiatry 22, 1208-1216.

Wallner, M., Hanchar, H. J., and Olsen, R. W. (2003). Ethanol enhances alpha 4 beta 3 delta and alpha 6 beta 3 delta gamma-aminobutyric acid type A receptors at low concentrations known to affect humans. Proc. Natl. Acad. Sci. U.S.A. 100, 15218-15223.

Wang, M., Backstrom, T., Sundstrom, I., Wahlstrom, G., Olsson, T., Zhu, D., Johansson, I. M., Bjorn, I., and Bixo, M. (2001). Neuroactive steroids and central nervous system disorders. Int. Rev. Neurobiol. 46, 421-459.

Wang, M., He, Y., Eisenman, L. N., Fields, C., Zeng, C. M., Mathews, J.,
Benz, A., Fu, T., Zorumski, E., Steinbach, J. H., Covey, D. F., Zorumski, C. F., and Mennerick, S. (2002) 3beta -hydroxypregnane steroids are pregnenolone sulfate-like GABA(A) receptor antagonists. J. Neurosci. 22, 3366-3375.

Wang, M., Rahman, M., Zhu, D., and Bäckström, T. (2006). Pregnenolone sulfate and zinc inhibit recombinan rat GABAA receptor through different channel property. Acta physiol. (Oxf.)188, 153-163.

Wang, M., Seippel, L., Purdy, R. H., and Backstrom, T. (1996). Relationship between symptom severity and steroid variation in women with premenstrual syndrome: study on serum pregnenolone, pregnenolone sulfate, 5 alpha-pregnane-3,20-dione and 3 alpha-hydroxy-5 alpha-pregnan-20one. J. Clin. Endocrinol. Metab. 81, 1076-1082.

Wang, M. D., Backstrom, T., and Landgren, S. (2000). The inhibitory effects of allopregnanolone and pregnanolone on the population spike, evoked in the rat hippocampalCA1 stratum pyramidale in vitro, can be blocked selectively by epiallopregnanolone. Acta Physiol. Scand. 169, 333-341.

Wang, M. D., Rahman, M., Zhu, D. Johansson, I. M., and Backstrom, T. (2007). 3Beta-hydroxysteroids and pregnenolone sulfate inhibit recombinant rat $\mathrm{GABA}(\mathrm{A})$ receptor through different channel property. Eur. J. Pharmacol. 557, 124-131.

Wardell, B., Marik, P. S., Piper, D., Rutar, T., Jorgensen, E. M., and Bamber, B. A. (2006). Residues in the first transmembrane domain of the Caenorhabditis elegans GABA(A) receptor confer sensitivity to the neurosteroid pregnenolone sulfate. Br. J. Pharmacol. 148, 162-172.

Weinbroum, A. A., Szold, O., Ogorek, D., and Flaishon, R. (2001). The midazolam-induced paradox phenomenon is reversible by flumazenil. Epidemiology, patient characteristics and review of the literature. Eur. J. Anaesthesiol. 18, 789-797.

Welberg, L. A., and Seckl, J. R. (2001). Prenatal stress, glucocorticoids and the programming of the brain. $J$. Neuroendocrinol. 13, 113-128.

Whiting, P. J. (2003a). GABA-A receptor subtypes in the brain: a paradigm for CNS drug discovery? Drug Discov. Today 8, 445-450.

Whiting, P. J. (2003b). The GABAA receptor gene family: new opportunities for drug development. Curr. Opin. Drug Discov. Devel. 6, 648-657.
Wieland, S., Belluzzi, J. D., Stein, L., and Lan, N. C. (1995). Comparative behavioral characterization of the neuroactive steroids 3 alpha$\mathrm{OH}, 5$ alpha-pregnan-20-one and 3 alpha-OH, 5 beta-pregnan-20-one in rodents. Psychopharmacology (Berl.) 118, 65-71

Wieland, S., Lan, N. C., Mirasedeghi, S., and Gee, K. W. (1991). Anxiolytic activity of the progesterone metabolite 5 alpha-pregnan-3 alpha-o1-20one. Brain Res. 565, 263-268.

Wihlback, A. C., Sundstrom-Poromaa, I., and Backstrom, T. (2006). Action by and sensitivity to neuroactive steroids in menstrual cycle related CNS disorders. Psychopharmacology (Berl.) 186, 388-401.

Wohlfarth, K. M., Bianchi, M. T. and Macdonald, R. L. (2002) Enhanced neurosteroid potentiation of ternary GABA(A) receptors containing the delta subunit. J. Neurosci. 22, 1541-1549.

Wolkowitz, O. M., Reus, V. I., Roberts, E., Manfredi, F., Chan, T., Ormiston, S., Johnson, R., Canick, J., Brizendine, L., and Weingartner, H. (1995). Antidepressant and cognition-enhancing effects of DHEA in major depression. Ann. N. Y. Acad. Sci. 774, 337-339.

Woodhull, A. M. (1973). Ionic blockage of sodium channels in nerve. J. Gen. Physiol. 61, 687-708.

Woodward, R. M., Polenzani, L., and Miledi, R. (1992). Effects of steroids on gamma-aminobutyric acid receptors expressed in Xenopus oocytes by poly(A)+ RNA from mammalian brain and retina. Mol. Pharmacol. 41, 89-103.

Wu, F. S., Gibbs, T. T., and Farb, D. H. (1991). Pregnenolone sulfate: a positive allosteric modulator at the $\mathrm{N}$ methyl-D-aspartate receptor. $\mathrm{Mol}$. Pharmacol. 40, 333-336.

Wu, Y., Wang, W., and Richerson, G. B. (2003). Vigabatrin induces tonic inhibition via GABA transporter reversal without increasing vesicular GABA release. J. Neurophysiol. 89, 2021-2034.

Yamada, J., Okabe, A., Toyoda, H., Kilb, W., Luhmann, H. J., and Fukuda, A. (2004). Cl- uptake promoting depolarizing GABA actions in immature rat neocortical neurones is mediated by NKCC1. J. Physiol. (Lond.) 557, 829-841.

Yang, L., Omori, K., Otani, H., Suzukawa, J., and Inagaki, C. (2003). GABAC receptor agonist suppressed ammonia-induced apoptosis in cultured rat hippocampal neurons by restoring phosphorylated BAD level. J. Neurochem. 87, 791-800. 
Yee, B. K., Hauser, J., Dolgov, V. V., Keist, R., Mohler, H., Rudolph, U., and Feldon, J. (2004). GABA receptors containing the alpha5 subunit mediate the trace effect in aversive and appetitive conditioning and extinction of conditioned fear. Eur. J. Neurosci. 20, 1928-1936.

Yeung, J. Y., Canning, K. J., Zhu, G., Pennefather, P., MacDonald, J. F., and Orser, B. A. (2003). Tonically activated GABAA receptors in hippocampal neurons are high-affinity, low-conductance sensors for extracellular GABA. Mol. Pharmacol. 63, 2-8.

Yu, R., Follesa, P., and Ticku, M. K. (1996). Down-regulation of the GABA receptor subunits mRNA levels in mammalian cultured cortical neurons following chronic neurosteroid treatment. Brain Res. Mol. Brain Res. 41, 163-168.

Yu, R., and Ticku, M. K. (1995a). Effects of chronic pentobarbital treatment on the GABAA receptor complex in mammalian cortical neurons. J. Pharmacol. Exp. Ther. 275, 1442-1446.

Yu, R., and Ticku, M. K. (1995b). Chronic neurosteroid treatment decreases the efficacy of benzodiazepine ligands and neurosteroids at the gamma-aminobutyric acidA receptor complex in mammalian cortical neurons.
J. Pharmacol. Exp. Ther. 275, 784-789.

Zhu, W. J., and Vicini, S. (1997). Neurosteroid prolongs GABAA channel deactivation by altering kinetics of desensitized states. J. Neurosci. 17, 4022-4031.

Zorumski, C. F., Mennerick, S., Isenberg, K. E., and Covey, D. F. (2000). Potential clinical uses of neuroactive steroids. Curr. Opin. Investig. Drugs 1, 360-369.

Conflict of Interest Statement: The author declares that the research was conducted in the absence of any commercial or financial relationships that could be construed as a potential conflict of interest.
Received: 05 July 2011; paper pending published: 25 July 2011; accepted: 14 September 2011; published online: 04 October 2011.

Citation: Wang M (2011) Neurosteroids and GABA-A receptor function. Front. Endocrin. 2:44. doi: 10.3389/fendo.2011.00044

This article was submitted to Frontiers in Neuroendocrine Science, a specialty of Frontiers in Endocrinology.

Copyright $\odot 2011$ Wang. This is an openaccess article subject to a non-exclusive license between the authors and Frontiers Media SA, which permits use, distribution and reproduction in other forums, provided the original authors and source are credited and other Frontiers conditions are complied with. 